\title{
Constructive Trusts in Canada
}

\section{ROBERT ChAMBERs}

In this article, the author discusses the role of constructive trusts in Canada, examining the connection between unjust enrichment and the constructive irust. In particular, the author focuses on the Supreme Court of Canada decision in Soulas v. Korkontzilas and argues that constructive trusts respond to two main categories of events, the acquisition of assets in breach of duty and intentions to beneft others.
L'auteur examine le róle de la fiducie par interprétation au Canada et son lien avec l'enrichissement sans cause. It se penche notamment sur I'arrè Soulas c. Korkontzilas de la Cour supreme du Canada el relive que l'application de la fiducie par interprétation peut sanctionner deux catégories de conduites: l'acquisition de biens par sutte d'un manquement $\dot{a}$ une obligation et l'intention de profiter à autrui.

\section{TABLE of CONTENTS}

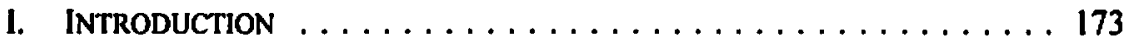

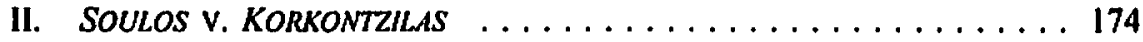

III. ASSETS WRONGFULLY ACQUIRED $\ldots \ldots \ldots \ldots \ldots \ldots \ldots \ldots 175$

A. RESPONSES to WRONGDONNG $\ldots \ldots \ldots \ldots \ldots \ldots \ldots \ldots$

B. Constructive TRUSt AS a

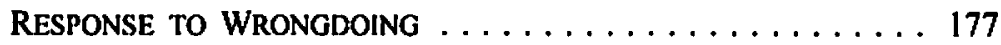

C. WRONGS, NOT UNJUST ENRICHMENT . . . . . . . . . . 177

D. WHICH WRONGS GIVE RISE

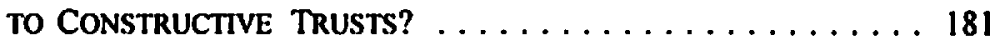

IV. INTENTIONS TO BENEFIT OTHERS $\ldots \ldots \ldots \ldots \ldots \ldots \ldots \ldots 182$

A. THE ROLE OF INTENTION $\ldots \ldots \ldots \ldots \ldots \ldots \ldots \ldots 183$

B. Contracts of Sale $\ldots \ldots \ldots \ldots \ldots \ldots \ldots \ldots \ldots \ldots$

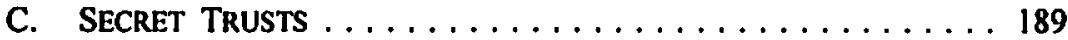

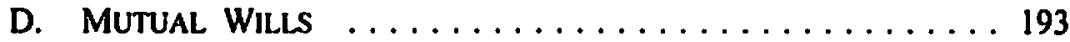

E. INCOMPLETE GIFTS $\ldots \ldots \ldots \ldots \ldots \ldots \ldots \ldots \ldots \ldots$

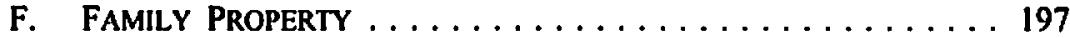

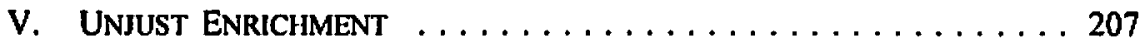

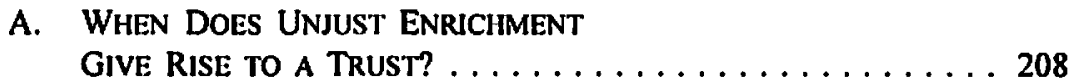

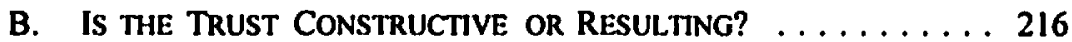

VI. CONCLUSION ....................... 219

\section{INTRODUCTION}

The occasion for this essay is provided by two recent events. One is the very kind invitation of the editors of the Alberta Law Review to contribute to this special issue on restitution and equity. The other is the decision of the Supreme Court of Canada in

Senior Lecturer, University of Melboume Law School, until the end of 1998 and then Associate Professor, University of Alberta Faculty of Law. Thanks are due to members of the University of Alberta Faculty of Law, who considered and discussed these ideas with me at a seminar in July 1998, and to Professor Peter Birks, who did the same during his visit to the University of Melbourne Law School in August and September 1998. The responsibility for errors is mine alone. 
Soulos v. Korkontzilas, ' which provides an important opportunity to reflect on the connection between unjust enrichment and the constructive trust and on the role of that trust in Canadian jurisprudence.

The inspiration for this essay was encountered six years earlier and is also twofold. One is an important book, Explaining Constructive Trusts, in which Dr. Elias shows that constructive trusts have significant roles other than restitution of unjust enrichment. The other is an important essay, "Restitution and Resulting Trusts" 3 in which Professor Birks shows that constructive trusts are not the only trusts which provide restitution of unjust enrichment.

The motivation for this essay also comes from the teaching of Professor Birks: these issues matter. ${ }^{4}$ Constructive trusts, like other rights enforceable at law or in equity, are legal responses to particular events. As the Soulos case demonstrates, there are high levels of doubt and disagreement over the events which give rise to constructive trusts. This is surprising. The constructive trust has been established for centuries and yet this uncertainty operates at a fundamental level. The issue which divided the Supreme Court in Soulos was whether constructive trusts respond only to unjust enrichment or to other events as well. This question is not one of nuance, but of a basic and most important kind. Unless answered clearly and correctly, the rational development of this area of the law in the next century is in jeopardy.

This essay presents the view that the majority of the Supreme Court of Canada was correct to conclude that the constructive trust is a response to not one, but at least two categories of events and that one of those categories is the acquisition of assets in breach of duty. However, contrary to the dominant Canadian assumption of the last two decades, the other main category of events to which constructive trusts respond is not unjust enrichment, but intentions to benefit others. If constructive trusts do respond to the category of events known as unjust enrichment, this is their minor role. The trusts raised in response to unjust enrichment are, in many cases, resulting.

\section{SOULOS V. KORKONTZILAS}

Soulos $v$. Korkontzilas is a simple case with a tiny wrinkle. A real estate agent had undertaken to attempt to purchase a particular parcel of land for his principal. Instead, he secretly purchased it in the name of his wife and told his principal that the land was unavailable. This was a clear breach of fiduciary duty and the only real issue concerned the proper response to that breach. The wrinkle, which led to a dissenting judgment in the Supreme Court of Canada, was the fact that the land had fallen in value. It was

[1997] 2 S.C.R. 217, 146 D.L.R. (4th) 214 (hereinafter Soulos cited to D.L.R.].

G. Elias, Explaining Constructive Trusts (Oxford: Clarendon Press. 1990).

P. Birks, "Restitution and Resulting Trusts" in S. Goldstein, ed., Equity and Contemporary Legal Developments (Jerusalem: Hamaccabi Press, 1992) at 335 (hereinafter Birks, "Restitution and Resulting Trusts"].

- See P. Birks, "Equity in the Modem Law: An Exercise in Taxonomy" (1996) 26 U. Western Australia L. Rev. I. 
worth less than the purchase price paid by the defaulting fiduciary and it could not be said that he had profited by his breach of duty.

Someone familiar with the law of trusts might be surprised to learn that this wrinkle was noteworthy, let alone a reason for taking the Soulos case to the highest level. It has long been established that fiduciaries, who acquire for their own benefit assets which they should acquire only for their principals, hold those assets on constructive trust for their principals." However, if, as Sopinka J. stated in dissent, "a constructive trust may only be ordered where there has been an unjust enrichment," then the loss of market value is no longer a tiny wrinkle, but a major worry. There was no apparent unjust enrichment of the defaulting fiduciary in Soulos. His actions had resulted in a financial loss to himself.

Fortunately, McLachlin J. recognized on behalf of the majority that unjust enrichment is not the only category of events to which constructive trusts respond:

[T]he law of constructive trust in the common law provinces of Canada embraces the situations in which English courts of equity traditionally found a constructive trust as well as the situations of unjust enrichment recognized in recent Canadian jurisprudence.?

She went on to identify two categories of events which give rise to constructive trusts:

The first category concerns property obtained by a wrongful act of the defendant, notably breach of fiduciary obligation... The second category concerns situations where the defendant has not acted wrongfully in obtaining the property, but where he would be unjustly enriched to the plaintiffs detriment by being permilted to keep the property for himself."

These two categories will be examined to see, first, that the former category should not be assimilated by the latter and, second, that many constructive trusts respond to events belonging in neither category.

\section{ASSETS WRONGFULLY ACQUIRED}

\section{A. RESPONSES TO WRONGDOING}

Before the link between constructive trusts and wrongful acts is examined, it is useful to consider briefly the variety of ways in which the law responds to wrongdoing. There are four main categories of legal responses to breach of duty: punishment, enforcement of the duty, compensation and restitution. The availability of a particular response depends on the nature of the duty and its breach and on the consequences of 
that breach. ${ }^{9}$ Punishment is most often encountered in criminal law. However, fines or punitive damages are possible in other areas of law.

Direct enforcement of the duty breached is less common. Examples are actions for the ejectment of persons wrongfully in possession of land or for an injunction to restrain a threatened breach of confidence. It must not be forgotten that some duties can be enforced directly in the absence of breach; e.g., specific performance of a contract of sale, restitution of a mistaken payment. However, there are others, such as the examples given above, where the duty is enforced only where there is a breach, or threatened breach, of that duty.

Compensation is a common response where a breach of duty causes loss (e.g., personal injury caused by careless driving or a loss of trust assets through a trustee's failure to invest them properly). Unlike punishment or direct enforcement of a duty, compensation is necessarily dependent on the consequences of the breach. Punishments are often linked to the consequences of a wrong (e.g., a length of a term of imprisonment might depend on whether a wound caused death, serious bodily harm, or slight injury) and the court's willingness to order performance of a duty might depend upon the consequences of its non-performance. However, these links are not logically necessary. In contrast, compensation is not possible unless the defendant's breach of duty has caused a loss to the plaintiff. The amount of compensation is measured by the value of the loss.

Like compensation, restitution depends directly upon the consequences of the breach. If a wrongdoer profits from a breach of duty, the victim may be able to obtain an account of profits and a judgment against the wrongdoer for the amount of the profit. ${ }^{10}$ If a wrongdoer acquires an asset through a breach of duty, it is sometimes possible to obtain a declaration that the wrongdoer holds that asset in trust for the victim. "In other cases where the defendant gains from a breach of duty, it might be possible to obtain an award of "restitutionary damages" measured by the value of that gain." These responses are restitutionary because they cause the wrongdoer to give up a benefit or asset received. As with compensation, the restitutionary response to a breach of duty is necessarily linked to the consequences of that breach. While compensation is measured by the loss to the plaintiff, restitution is dependent on the receipt of a benefit or asset by the defendant.

As a response to breach of duty, restitution is less common than compensation, possibly because the consequences which trigger restitution (profits made or assets acquired) are less common than loss. However, there is another reason. The law does

See P. Cane, The Anatomy of Tort Law (Oxford: Hart Publishing, 1997) at 96-122; P. Birks, ed., Wrongs and Remedies in the Twenty-First Century (Oxford: Clarendon Press, 1996) (hereinafter Birks, ed., Wrongs and Remedies]. 
not permit restitution in response to every breach of duty, even where the defendant has acquired some benefit or asset as a result. For example, whether restitution should be available when a defendant makes a profit through a breach of contract is a question currently under debate. ${ }^{13}$ Restitution is more common in cases where the duty breached is equitable, such as a duty of loyalty or confidence, or involves an interference with property rights, such as trespass to land. ${ }^{14}$

\section{B. Constructive Trust as a Response to Wrongdoing}

One of the older uses of the constructive trust is to remove from trustees assets acquired in breach of their fiduciary duties. In Keech v. Sandford, ${ }^{15}$ a trustee held a lease in trust for an infant. At the end of the lease, the trustee applied for a renewal of the lease for the benefit of the infant. The landlord refused to renew for the infant's benefit, but granted a renewal for the trustee's own benefit. Lord King C. stated, "I must consider this as a trust for the infant," and decreed that the trustee assign the lease to the infant, be indemnified from the tenant's covenants in the lease, and give an account of profits earned since the renewal. ${ }^{16}$

The response in Keech v. Sandford was restitution. The constructive trust was imposed to cause the trustee to give up the asset received. This was not punishment. The trust, coupled with an indemnity and account of profits, removed the benefit to the trustee and nothing more. This was not compensation for the infant's loss nor specific enforcement of the trustee's duty to the infant. As Lord King C. said, "the trustee should rather have let the lease run out, than to have had it to himself." ${ }^{17}$ The response was simply to take from the trustee something which the law said he should not have obtained for his own benefit.

\section{Wrongs, Not UnJUST ENRICHMENT}

Although there is no difficulty describing the response in Keech v. Sandford as restitution (i.e., a giving up of benefits or assets received), ${ }^{18}$ it must not be forgotten that it is restitution in response to a wrong. There are potential difficulties if it is described as restitution of unjust enrichment. Unjust enrichment (properly so called)

See A-G v. Blake, [1998] I All E.R. 833 at 843-46 (C.A.): G. Virgo, "Clarifying Restitution for Wrongs" [1998] R.L.R. I18; W. Goodhar, "Restitutionary Damages for Breach of Contract" [1994] R.L.R. 3; L.D. Smith, "Disgorgement of the Profits of Breach of Contract: Property, Contract and 'Efficient Breach'"' (1994) 24 Can. Bus. L.J. 121; P.D. Maddaugh \& J.D. McCamus, The Law of Restitution (Toronto: Canada Law Book, 1990) at 432-38.

14 Burrows, Restitution, supra note 12 at 381-418; A. Burrows, Remedies for Torts and Breach of Contract, 2d ed. (London: Butterworths, 1994) at 286-314.

is (1726), Sel. Cas. Ch. 61, 25 E.R. 223, [1558-1774] All E.R. Rep. 230.

16. $\quad$ bid.

1 Ibid.

1* P. Birks, An Introduction to the Law of Restitution, rev. ed. (New York: Oxford University Press, 1989) at 12 [hercinafter Birks, Introduction]; P. Birks, "Misnomer" in W.R. Cornish et al., Restinution Past, Present and Future (Oxford: Hant Publishing, 1998) at 12-13 (hereinafter Birks, "Misnomer"]; L.D. Smith, "The Province of the Law of Restitution" (1992) 71 Can. Bar Rev. 672 at 694-99 [hereinafter Smith, "The Province of the Law of Restitution"]. 
does not depend on wrongdoing, but occurs where someone receives a benefit at another's expense in circumstances which the law regards as unjust (i.e., reversible). The Canadian description of that event, borrowed from Quebec civil law, ${ }^{19}$ is in somewhat different terms. As Dickson J. stated in Pettkus v. Becker, "there are three requirements to be satisfied before an unjust enrichment can be said to exist: an enrichment, a corresponding deprivation and absence of any juristic reason for the enrichment." 20

It is only with difficulty that these descriptions of unjust enrichment can be applied to cases like Keech v. Sandford and Soulos v. Korkontzilas. The problem lies not so much with describing the defendant as enriched or describing the enrichment as unjust. The difficulty is that the enrichment is not obtained at the plaintiff's expense or, in Canadian terms, the plaintiff has not suffered a corresponding deprivation. It will be helpful to deal with these three elements separately.

First, if a definition of 'enrichment' is broad enough, it can cope with cases like Soulos, where the impugned transaction was financially disadvantageous for the defendant. The definition found in the American Law Institute's Restatement of the Law of Restitution would suffice:

A person is enriched if he has received a benefit... A person confers a benefit upon another if he gives to the other possession of or some other interest in money, land, chattels, or choses in action, performs services beneficial to or at the request of the other, satisfies a debt or a duty of the other, or in any way adds to the other's security or advantage."

Note that this definition of benefit is not linked to market value. The defendant in Soulos obtained an interest in land. That right is a benefit regardless of its value in relation to the defendant's cost of acquisition. Since the constructive trust is imposed to effect restitution and not punishment, the plaintiff who wishes to enforce the trust must reimburse the defendant for the expense of acquiring, maintaining and improving the asset. ${ }^{22}$ It cannot matter whether the reimbursement is greater or less than the value of the asset. It would be absurd if a constructive trust of an asset was possible so long as the asset was acquired for $\$ 10$ less than its market value but not if the defaulting fiduciary paid $\$ 10$ more. A system of property law could not survive if

Maddaugh \& McCamus, supra note 13 at 29; Smith, "The Province of the Law of Restitution," ibid. at 677; M. Mclnnes, "The Canadian Principle of Unjust Enrichment" (1999) 37 Alta. L. Rev. 1; see G.S. Challies, The Doctrine of Unjustified Enrichment in the Law of the Province of Quebec, 2d ed. (Montreal: Wilson LaFleur Limited, 1952) at 58; B. Nicholas, "Unjustified Enrichment in the Civil Law and Louisiana Law" (1962) 36 Tulane L. Rev. 605; R. Zimmermann, The Law of Obllgations (Oxford: Oxford University Press, 1996) at 883-84. 1937) at 12 [hereinafter Restatement of Restitution]. 
fluctuations in market value caused property rights to fade in and out like weak radio signals.

Secondly, there is not much difficulty describing the "enrichment" in Soulos as "unjust" if that adjective is understood to mean simply that there is a reason for requiring the defendant to give up that enrichment. ${ }^{23}$ The defendant's acquisition of the land was unjust in that case because it was done in breach of a duty owed to the plaintiff. The reason for restitution is the wrongdoing. In cases properly falling within the category of unjust enrichment, the unjustness is a different kind of event. Usually, it is something which shows that the person who provided an enrichment to another did not intend to benefit that other, as, for example, where benefits are conferred by mistake or under undue influence or for a consideration which has failed. There need not be a wrong involved, just a reason for deciding that the particular transaction is reversible.

Although the defendant's acquisition of the land in Soulos can be described as "unjust enrichment," serious difficulties are encountered when that phrase is used in that fashion. In Soulos, restitution (by way of constructive trust) was a response to a breach of duty. Calling that event "unjust enrichment" obscures the fact that it is very different from those cases in which a person innocently received a benefit from another and was required to return that benefit or give up its value to that other. The use of a single term to describe two different categories of events is likely to confuse and, for that reason alone, should be avoided, even if that term fairly described both categories. However, the phrase 'unjust enrichment' is not an apt description of the reason for restitution in Soulos.

"Unjust enrichment" is shorthand for "unjust enrichment at the expense of another."24 The Canadian translation of this is "an enrichment, a corresponding deprivation and absence of any juristic reason for the enrichment."2s These are descriptions of that category of events in which mistaken payments are found. Every case within that category involves persons who have received benefits or assets from others and are being asked to return those things or pay for their value. It takes some sleight of hand to describe the enrichment in Soulos v. Korkontzilas as being at the plaintiff's expense and harder still to say that the plaintiff has suffered a corresponding deprivation. In Soulos, the plaintiff did not transfer the land to the defendant nor did he pay for it. In truth, he was financially better off as a result of the defendant's breach of fiduciary duty. The same was true of the plaintiffs in Boardman v. Phipps. ${ }^{26}$ In that case, the defendant had acquired shares in breach of his fiduciary duty to the plaintiffs and held those shares on constructive trust for the plaintiffs even though his actions had otherwise produced a large profit for them. It is only artificially that we can describe the defendant's enrichment in that case as having been gained at the plaintiffs' expense

23 Birks, Introduction, supra note 18 at 19.

$24 \quad$ bid. at 16.

2s Penkus v. Becker, supra note 20 at 274, Dickson J.

26. [1967] 2 A.C. 46, [1966] 3 All E.R. 721. 
or through their deprivation. It is dangerous to try since that is not an element of the plaintiffs' claim.

Soulos can be described as a case of unjust enrichment only if a breach of duty towards a person is treated as if it is an expense to, or deprivation of, that person. This is a convenient way of drawing together restitution of unjust enrichment and restitution as a response to wrongdoing. ${ }^{27}$ However, as Professor Birks states:

[T]here are really two quite different 'principles' masquerading as one; and they behave differently.... When the principle against unjust enrichment is neither divided to reveal the ambiguity of 'at the expense of nor restated to bring 'unjust' firmly into contact with the cases, this error or overstatement in relation to wrongs does not go away. It is merely hidden. It remains a latent defect whose presence, sensed but not identified, has contributed to the suspicion in which the language of unjust enrichment has been held. ${ }^{2 \pi}$

The time for masquerading and hiding has passed. It is more important than ever that lawyers and judges speak and write plainly. It cannot be denied that the events properly described as unjust enrichment (e.g., a mistaken payment) are of a different order than the events described as wrongdoing (e.g., breach of fiduciary duty). Language which conceals this important distinction should be avoided.

There are, as McLachlin J. recognized, ${ }^{29}$ cases in which unjust enrichment and wrongdoing are both present. For example, in El Ajou v. Dollar Land Holdings plc, ${ }^{30}$ the plaintiff's agent was bribed to invest the plaintiff's assets in worthless shares. There was both an unjust enrichment at the expense of the plaintiff (a transfer of assets without consent) and a wrong done to the plaintiff (fraud). Either event should support the plaintiff's right to restitution. When dealing with overlapping causes of action, one must take special care not to confuse the essential elements of each claim. It is an error to assume either that wrongdoing is a necessary part of a claim for restitution of unjust enrichment or that unjust enrichment and corresponding deprivation (unjust enrichment at the expense of another) are essential to a claim for restitution in response to a breach of duty."

When dealing with breaches of duty, the language of unjust enrichment is inappropriate and should be avoided. Instead, the inquiry must be: (a) was there a breach of duty, (b) what were the consequences of that breach, and (c) how does the law respond when a breach of that duty produces those consequences? These questions, about duty, breach, causation and response, belong to the law of wrongs, not the law of unjust enrichment. They can be dealt with as part of the law of restitution, as long

$27 \quad$ Birks, Intraduction, supra note 18 at 313; McInnes, supra note 19.

2. Birks, Introduction, ibid. at 24-25; also see Birks, "Misnomer," supra note 18 at 14.

29 Soulos, supra note 1 at 227-28.

[11 [1993] 3 All E.R. 717, rev'd [1994] 2 All E.R. 685 (C.A.).

31 This confusion was at work in Rosenfeldt v. Olson (1986), 25 D.L.R. (4th) 472 (B.C.C.A.); see G. Virgo, "The Law of Restitution and the Proceeds of Crime" [1998] R.L.R. 34 at 42. 
as it is understood that restitution is a response to both wrongdoing and unjust enrichment and possibly other events as well. As Dr. Smith said:

It is true that the only response for the cause of action in unjust enrichment appears to be restitution; but it is not true that restitution can only be had where one has established the cause of action in unjust enrichment. Restitution for wrongs is the granting of a restitutionary remedy for a cause of action other than the cause of action in unjust enrichment; as a result, there is no need in restitution for wrongs to have any regard for the elements of the cause of action in unjust enrichment. ${ }^{32}$

\section{Which Wrongs Give Rise to Constructive Trusts?}

A wrong will give rise to a constructive trust if the inquiry leads to two conclusions: first, that the wrongdoer acquired an asset (capable of being the subject matter of a trust) by means of a breach of a duty owed to the victim and, second, that the breach was of the kind for which a constructive trust is considered an appropriate response (i.e., a court of equity will require the wrongdoer to transfer that asset to the victim).

Accounts of profits and constructive trusts can both be used as restitutionary responses to wrongdoing. It is sometimes assumed that both respond to the same event, the only difference being that one is a right in personam to be paid the value of the profits and the other is a right in rem to the profits themselves. However, the events which give rise to those responses are similar but slightly different events. An account of profits is possible when the wrongdoer has made a profit in breach of duty. A constructive trust is possible when the wrongdoer has obtained an asset in breach of duty.

In most cases where restitution for wrongs is possible, both events will have occurred: the wrongdoer will have received an asset and earned a profit thereby. However, one can happen without the other. A wrongdoer might profit without receiving an asset capable of being the subject matter of a trust (e.g., a bribe through provision of services) and, conversely, a wrongdoer might receive an asset without making a profit, as in Soulos. Where an account of profits and a constructive trust are available in the same case, they are triggered by contemporaneous, but separate, events and, therefore, the responses differ. An account of profits produces a debt equal to the net profits made, while a constructive trust attaches to the entire asset received, with enforcement of that trust conditional on payment of the wrongdoer's expenses in acquiring, maintaining and improving that asset.

As discussed above, the consequences of a breach of duty limit the potential responses to that breach. Compensation is possible only where the breach causes a loss to the victim and restitution only where the breach produces a benefit or asset for the wrongdoer. Where the consequences mean that restitution is potentially available, the law faces two questions which may be difficult to answer: is this the sort of wrong which gives the victim a right to restitution and, if so, should that right be (or include) 
a right in rem (a constructive trust) or merely a right in personam (to an account of profits or restitutionary damages)? In the famous English case of Lister v. Stubbs, ${ }^{33}$ the Court of Appeal made it clear that an agent's receipt of a bribe was a wrong for which an account of profits would lie, but not a constructive trust. A century later, in the now equally famous New Zealand case of $A-G$ Hong Kong v. Reid, ${ }^{34}$ the Privy Council advised that a bribed fiduciary holds the bribe monies on constructive trust for his or her principal from the moment of receipt. The change of direction is clear, but it is not yet possible to answer these questions with any certainty. There are gain producing wrongs for which the appropriate response is unknown.

What will Canadian courts do? McLachlin J. made some suggestions in Soulos v. Korkontzilas. However, as Dr. Smith pointed out, ${ }^{35}$ it is not at all clear that the suggested path is one which the Supreme Court of Canada would really wish to tread. Relying on the work of Professor Goode, ${ }^{36}$ McLachlin J. identified "the prerequisites for a constructive trust based on wrongful conduct." ${ }^{37}$ Included among the "four conditions which generally should be satisfied" is a requirement that the "assets in the hands of the defendant must be shown to have resulted from deemed or actual agency activities of the defendant in breach of his equitable obligation to the plaintiff." ${ }^{38}$ This restriction would favour the result in Lister v. Stubbs over that in $A-G$ Hong Kong v. Reid, since it cannot be said that the receipt of a bribe is part of an agent's activities, deemed or actual. Although there is much to be said for this approach, ${ }^{39}$ Lister v. Stubbs does have Canadian opponents ${ }^{40}$ and it would not surprise observers in Canada and elsewhere to see $A-G$ Hong Kong v. Reid approved here. Also, one wonders why constructive trusts should be restricted to cases where the duty breached is equitable. To use an extreme example, should money paid to a hired killer be held in trust for the victim's estate or would a Canadian court prefer other responses to the wrong, such as compensation for loss and possibly statutory forfeiture of the proceeds of crime?

\section{INTENTIONS TO BENEFIT OTHERS}

Having identified, and separated from the mass, those situations in which constructive trusts are raised in response to breaches of duty, it is time to turn to what remains and see whether all are cases of restitution of unjust enrichment, as McLachlin J. seems to suggest. As discussed in this section, they are not. In fact, most are not. Once restitution for wrongs is excluded, a pattern emerges of constructive trusts raised

(1890), 45 Ch. D. 1, [1886-90] All E.R. Rep. 797.

[1994] I A.C. 324, [1994] I All E.R. I, [1994] I N.Z.L.R. I.

L.D. Smith. "Constructive Trusts - Unjust Enrichment - Breach of Fiduciary Obligation: Soulos v. Korkontzilas" (1997) 76 Can. Bar Rev. 539 at 545-46.

R.M. Goode, "Property and Unjust Enrichment" in A. Burrows, ed.. Essays on the Law of Restitution (Oxford: Clarendon Press, 1991) 215 |hereinafter Goode. "Property and Unjust [Enrichment"].

Soulos, supra note 1 at 230.

thid.

P. Bisks, "Property in the Prolits of Wrongdoing" (1994) 24 U. Western Australia L. Rev. 8: Burrows, Restitution, supra note 12 at 43-44, 409-14; J.C. Smith, "Lister v. Srubbs and the Criminal Law" (1994) 110 L.Q.R. 180.

Sec Maudaugh \& McCamus, supra note 13 at 93-94, 619-20. 
to give better effect to intentions to benefit others. Dr. Elias classified the constructive trusts in these situations as "perfectionary" (i.e., a trust created to "perfect" an intention to transfer an asset) to distinguish them from the "restitutionary" constructive trusts discussed above. ${ }^{41}$

This statement will no doubt seem controversial (if not heretical) to many Canadians. However, it can be demonstrated that perfection of intention is one of the constructive trust's major roles. The role of intention in the creation of trusts is discussed first. The remainder (and bulk) of this section is devoted to bricf looks at five situations in which this perfectionary role can be seen: contracts of sale, secret trusts, mutual wills, incomplete gifts, and the division of family property on the breakdown of a marriage or similar relationship. The discussion of the trusts which do respond to unjust enrichment takes place in the following section.

\section{A. TIIE ROI.E OF INTENTION}

It is uncontroversial that an express trust is created by the settlor's properly manifested intention to creatc that trust. The main issues surrounding the creation of an express trust are: (a) did the settlor really mean to create a trust, (b) was that intention expressed in the manner required by law, (c) did the intended trustee obtain title to the assets which form the subject matter of the intended trust, (d) is that subject matter identifiable, and (e) is the purpose of the intended trust sufficiently defined and acceptable? If the first requirement is met, but one of the others is not, then the settlor will have intended but failed to create an express trust. That intention, like other intentions to benefit others, can be relevant to the creation of resulting and constructive trusts. However, these three categories of trusts (express, resulting and constructive) respond to intention in different ways.

Resulting trusts often arise in cases where an express trust was intended but failed to take effect or run its full course. The fact that an express trust was intended is significant because it indicates that the trustee was not intended to receive the property for his or her own benefit. For example, if a settlor conveys land to a trustee and orally tells the trustee to hold that land in trust for a beneficiary, the intention to create an express trust is clear, but that trust will fail to arise because it does not comply with the requirement, inherited from the Statute of Frauds 1677 , that it be manifest in writing. However, the trustee will hold the land on resulting trust for the settlor because the settlor's intention to create a trust shows that he or she did not intend to benefit the trustee. $^{42}$

Resulting trusts arise in a variety of situations and, in each, the event giving rise to the resulting trust is the receipt of an asset by someone who was not intended to have

$4 \quad$ Ejias, supra note 2.

12 Hodgson v. Marks, [1971] Ch. 892 at 933, [1971] 2 All L.R. 684 at 689 (C.A.) [hereimatter Hodgson v. Marks cited to All E.R.]. 
the benefit of that asset. ${ }^{43}$ Intention plays a crucial role in the creation of resulting trusts. Unlike an express trust, a resulting trust is not the direct product of an intention to create that trust. However, the lack of intention to benefit another is a key part of the events to which resulting trusts respond. As Professor Birks states:

There is a fine but important distinction between intent conceived as creative of rights, as in an express trust or a contract, and intent conceived as a fact which, along with others, calls for the creation of rights by operation of law. ${ }^{4}$

The problems understanding resulting trusts have been caused by over-emphasising the role of intention in their creation. The important negative role of intention in the creation of a resulting trust (as a response to the lack of intention to benefit another) has been mistaken for a positive role (that a resulting trust responds to an intention to create a trust for oneself). The problems understanding constructive trusts have been caused by a similar error working in the opposite direction: under-emphasising the role of intention in their creation. Like resulting trusts, constructive trusts arise by operation of law in response to particular events and are not the direct products of properly manifested intentions to create them. However, in many situations, intentions to benefit others are at the centre of the events to which constructive trusts respond.

An impediment to the proper development of the constructive trust is the oft-repeated belief that intention has no role whatsoever in the creation of constructive trusts. For example, Professor Waters states:

An express trust arises out of the intention of the settlor; the constructive trust comes into existence, regardless of any party's intent, when the law imposes upon a party an obligation to hold specific property for another."s

Professors Oosterhoff and Gillese work from the same premise:

It is clear that the constructive trust has nothing whatsoever to do with intention, but is imposed by law to prevent injustice."

These statements are true with respect to those constructive trusts which arise in response to the acquisition of an asset in breach of duty. In most of these cases, as in Soulos, the wrongdoer intends to acquire an asset for his or her own benefit from someone who intends to transfer the beneficial ownership of that asset to the wrongdoer. The transaction takes place and a constructive trust arises without the knowledge of the victim of the breach of duty, for whose benefit the trust of the asset

A.H. Oosterhoff \& E.E. Gillese, Text, Commentary and Cases on Trusts, 4th ed. (Toronto: Carswell, 1992) at 274-76; R. Chambers, Resulting Trusts (Oxford: Clarendon Press, 1997) at 3235, 100-102 [hereinafler Chambers, Resulling Trusts]; P.J. Millett, "Restitution and Constructive Trusts" (1998) 114 L.Q.R. 399 at 401; cf. W.J. Swadling, "A New Role for Resulting Trusts?" (1996) 16 Legal Studies 110.

4 Birks, Introduction, supra nole 18 at 65.

4s D.W.M. Waters, Law of Trusts in Canada, 2d ed. (Toronto: Carswell, 1984) at 377.

45. Supra note 43 at 17. 
is imposed. Of course, intention can be relevant to the formation of the underlying duty and its breach (e.g., whether the defendant undertook a fiduciary duty to the plaintiff and whether the plaintiff consented to the defendant's profit), but those are separate issues. Where a constructive trust is imposed in response to the acquisition of an asset in breach of duty, it does so regardless of the parties' intentions concerning the beneficial ownership of that asset.

However, with deep respect for Professors Gillese, Oosterhoff, and Waters, the separation of intention and constructive trust cannot be reconciled with other situations in which constructive trusts arise, such as the five discussed below: contracts of sale, secret trusts, mutual wills, incomplete gifts, and family property. These three distinguished Canadian experts on the law of trusts are by no means alone in their views on the creation of constructive trusts. Those ideas echo throughout the commonlaw world. However, outside North America, the prevailing view tends to be nervously contradicted soon after it is uttered.

For example, in the Australian case of Allen v. Snyder, Glass J.A. stated, "Unlike express and implied trusts, which reflect actual intentions, [constructive trusts] are imposed, without regard to the intentions of the parties, in order to satisfy the demands of justice and good conscience."47 However, three pages later he said, "when it is called a constructive trust, it must not be forgotten that the courts are giving effect to an arrangement based upon the actual intentions of the parties, not a rearrangement in accordance with considerations of justice, independent of their intentions."

Twenty years later in England, Mr. Oakley begins his work on constructive trusts by stating, "Unlike all other trusts, a constructive trust is imposed by the court as a result of the conduct of the trustee and therefore arises quite independently of the intention of any of the parties."49 The footnote to this sentence warns the reader that, "There are, of course, circumstances where constructive trusts are imposed to give effect to the express and implied intentions of the parties." 30

This is not intended to single Glass J.A. or Mr. Oakley out for criticism or to show any disrespect for their important contributions to equity jurisprudence. This merely demonstrates the great tension which exists in other parts of the common-law world between the prevailing belief and the observations which are inconsistent with it. Perhaps more surprising than these juxtapositions is the relative lack of such tensions in Canada. 


\section{B. Contracts of Sale}

Possibly the oldest, and certainly the most frequent, use of the constructive trust is to perfect a specifically enforceable promise to transfer an asset to another. ${ }^{\text {st }}$ As Jessel M.R. said in Lysaght v. Edwards:

It appears to me that the effect of a contract for sale has been settled for more than two centuries... [T]he moment you have a valid contract for sale the vendor becomes in equity a trustee for the purchaser of the estate sold, and the beneficial ownership passes to the purchaser, the vendor having a right to the purchase-money, a charge or lien on the estate for the security of that purchase-money, and a right to retain possession of the estate until the purchase-moncy is paid, in the absence of express contract as to the time of delivering possession. ${ }^{32}$

It is clear that the constructive trust arises from the moment the contract is made, provided the promise to transfer the asset is specifically enforceable. ${ }^{33}$ If, contrary to the expectations of the parties, the contract never was specifically enforceable, then the trust did not arise. If supervening events prevent specific performance of the contract, then the trust of that asset ceases. However, if the vendor sells the asset in breach of contract (and trust), a trust can attach to the proceeds of sale. ${ }^{54}$

The constructive trust in this situation is commonly associated with the sale of land. However, the same principles apply to any specifically enforceable contract to transfer a property right, including the sale of rare or unique chattels. ${ }^{55}$ As Lord Westbury C. said in Holroyd v. Marshall:

A contract for valuable consideration, by which it is agreed to make a present transfer of property, passes at once the beneficial interest, provided the contract is one of which a court of equity will decree specific performance.... [T]he vendor becomes a trustee for the vendet; subject, of course, to the contract being one to be specifically performed. And this is true, not only of contracts relating to real estate, but also to contracts relating to personal property, provided that the latter are such as a court of equity would direct to be specifically performed. ${ }^{\text {st }}$

Contracts to grant security interests are routinely regarded as specifically enforceable. ${ }^{57}$ One could say that this produces a constructive trust of a security interest. However, the word "trust" is normally reserved to describe equitable beneficial

S.F.C. Milsom, Historical Foundations of the Common Law, 2d ed. (London: Butterworths, 1981) at 223-24; A.W.B. Simpson, A History of the Common Law of Contract: The Rise of Action of Assumpsit (Oxford: Clarendon Press, 1987) at 346-47; Oakley, ibid. at 275. (1876), 2 Ch. D. 499 at 506. See R.E. Megarry \& H.R. Wade, The Law of Real Property, 5th ed. (London: Stevens \& Sons Limited, 1984) at 602-604. Martin Commercial Fueling Inc. v. Virtanen (1997), 144 D.L.R. (4th) 290 (B.C.C.A.); Bunny Indusiries Lid. v. FSW Enterprises Poy Lid., [1982] Qd. R. 712.

s4 Bunny Indusiries Lid. v. FSW Enterprises Poy Lid., Bbid.

" Dougan v. ley (1946), 71 C.L.R. 142; cf., Re Wait [1927] 1 Ch. 606, [1926] All E.R. Rep. 433; and Humboldt Flour Mills Co. LId. v. Boscher (1974), 50 D.L.R. (3d) 477 (Sask. C.A.). (1862), 10 II.L.C. 19] at 209, II E.R. 999, [1861-73] All E.R. Rep. 414 at 417. Ibid; Royal Bank of Canada v. Grobman (1977), 18 O.R. (2d) 636; Re Collens (1982), 140 D.L.R. (3d) 755 (Alta. Q.B.). 
ownership, so the product is described instead as an equitable mortgage or charge. It is also common for lawyers to speak of equitable leases, rather than constructive trusts of leases, although the latter description is not out of place, since an equitable lease is the beneficial ownership of an estate in land and not a security interest.

The constructive trust arising on a contract of sale should not be confused with the purchaser's lien which arises if all or part of the purchase price is paid before the formal transfer of title. The event which gives rise to the constructive trust is the specifically enforceable promise to transfer a property right, not the payment of the purchase price. Payment before formal transfer gives the purchaser an equitable lien over the asset to be transferred. ${ }^{58}$ This is a security interest arising by operation of law to protect the purchaser's entitlement to a refund of any part of the purchase price if the sale cannot be completed. The purchaser's lien lies dormant, submerged in the greater beneficial ownership of the constructive trust, while the contract remains specifically enforceable. It has been suggested that the "extent of the [purchaser's] equitable interest is measured by the amount of the purchase moneys paid." ${ }^{9}$ This is true of the purchaser's lien. However, the constructive trust attaches to the entire asset, whatever its value, and arises independently of payment. It would be better to view that trust as subject to the vendor's rights to possession and to be paid the full purchase price, rather than as measured by the amount paid.

Why does a constructive trust arise in this situation? The parties intended to pass title on the date agreed for formal transfer, not to create a trust. As Mr. Oakley states, "it is clear that the trust arises by operation of law." What is the nature of the event calling for equity's intervention in this manner? It cannot be restitution for breach of duty. The constructive trust arises at the outset. A breach of promise is not required. Even if the vendor does break the promise to transfer the asset, it cannot be said that the asset was acquired through that breach of duty. There may be a duty to make restitution of the purchase price, but that is a personal obligation secured by the purchaser's lien. It is not the source of the constructive trust.

The event creating the constructive trust is not unjust enrichment. The asset subject to that trust has not been received at the expense of the purchaser. The duty to refund the purchase price can properly be described as restitution of unjust enrichment (money paid for a consideration which has failed), ${ }^{61}$ but that is separate from, and not the source of, the constructive trust. It will often be true that a failure to keep a promise will leave the promisor better off and the promisee (or other persons chosen to receive the benefit of the performance of that promise) worse off. However, that is not unjust

Rose v. Watson (1864), 10 H.L.C. 672, II E.R. I187; Whitbread \& Co. Ltd. v. Watt, [1902] 1 Ch. 835 (C.A.); J.A.R. Leaseholds Lid. v. Tormet Ltd. and Kaye, [1965] I O.R. 347, 48 D.L.R. (2d) 97 (C.A.); Lehmann v. BRM Enterprises L.dd. (1978), 88 D.L.R. (3d) 87 (B.C.S.C.).

Bunny Industries LAd. v. FSW Enterprises Pty Lid., supra note 53 at 715, Connolly J.; also sec Rose v. Watson, ibid; S. Worthington, Proprietary Imlerests in Commercial Transactions (Oxford: Clarendon Press, 1996) at 207-208.

Oakley, supra note 49 at 304.

Chillingworth v. Esche, [1924] 1 Ch. 97, [1923] All E.R. Rep. 97 (C.A.); Guardian Ocean Cargoes Lid. v. Banco do Brasil SA, [1994] 2 Lloyd's L.R. 152 (C.A.). 
enrichment. If it were otherwise, the law of unjust enrichment would swallow up the law of contracts and almost every other area of law, since the same could be said about failures to pay compensation for losses caused, taxes due, child support payments, etc.

It is clear that the source of the constructive trust is the specifically enforceable promise to transfer an asset. The trust rises and falls with that promise. There are two questions to address: why does equity compel the performance of that promise and why does the power to compel performance of a promise to transfer an asset lead to the creation of a trust of that asset in advance of that performance?

The first question is relatively straightforward. Although much could be said, and has been written, about the enforcement of promises, the simple explanation given is that damages would be an inadequate substitute for performance in those cases in which specific performance is available. A judgment for the payment of money would not place the purchaser sufficiently close to the position he or she would attain if the promise had been performed. The promised land is not quite like any other. ${ }^{62}$ The same is true of many chattels. In some cases, duplicate chattels may exist but be hard to find. ${ }^{63}$ Although security interests are common place, a right to sue for damages for breach of a promise to provide a security interest is no substitute for performance. It is the same as not having that interest. In these cases, equity regards the common-law response as inadequate and intervenes.

The second question is a little harder. Why does beneficial ownership move to the purchaser in advance of the formal transfer? Having made a binding promise to transfer an asset, the vendor's relationship to that asset changes. As Dr. Penner states, "The owner shifts from treating the property as something to be used to enhance his interests to treating it as something to be traded." ${ }^{64}$ Immediately prior to making that promise, the vendor had the full beneficial use and enjoyment of that asset allowed by law. ${ }^{\text {os }}$ The promise reduced the vendor's property right essentially to the right to possession of the asset until transfer and the right to receive the capital value of that asset on transfer (with the latter right secured by a vendor's lien if formal transfer occurs before the purchase price is paid in full). The rest of the benefit of the vendor's legal property right has passed to the purchaser and takes on a separate existence in equity as a constructive trust.

The changing relationships of the parties to the asset in question are plain in many contracts for the sale of a home. The vendors are looking forward to their next home, needing a roof over their heads until then, and wanting to get the capital value out of

But see Semelhago v. Paramadevan, [1996] 2 S.C.R. 41S, 136 D.L.R. (4th) 1; C.J. Berger, "The Influence of Law and Economics on Real Estate Contract Enforcement" in S. Goldstein, ed., Equity and Contemporary Legal Developments (Jerusalem: Hamaccabi Press, 1992) 173.

Dougan v. Ley (1946), 71 C.L.R. 142.

J.E. Penner, The Idea of Property in Law (Oxford: Clarendon Press, 1997).

See A.M. Honore, "Ownership" in A.G. Guest, ed., Oxford Essays in Jurisprudence (Oxford: Clarendon Press, 1961) at 107; reprinted in T. Honore, Making Law Bind: Essays Legal and Philosophical (Oxford: Clarendon Press, 1987) 161; J.E. Penner, "The 'Bundle of Rights' Picture of Property" (1996) 43 U.C.L.A. L. Rev. 711 at 742. 
the present home to pay for the next. The purchasers have committed themselves, probably to the exclusion of other choices, to what they have begun to describe as "our new home" and are deeply concerned about the preservation of that home. The reality, which equity recognizes, is that the beneficial ownership has shifted.

A vendor, who makes a specifically enforceable promise to transfer an asset, has chosen to dispose of his or her options with respect to that asset. As Lord O'Hagan stated in Shaw v. Foster, "[b]y the contract of sale the vendor in the view of a Court of Equity disposes of his right over the estate, and on the execution of the contract he becomes constructively a trustee for the vendee."66 $\mathrm{Dr}$. Elias suggests that, when someone makes a choice to dispose of his or her options in favour of another, it is out of respect for the autonomy of the individual that equity treats that choice as binding. He writes:

The power to dispose of one's options in favour of another person is an integral aspect of the fundamental capacity of the individual to make and realize such dispositive or other plans as the pleases. We could not take the capacity seriously - we would begin to say that there should be no power to dispose at all - if we took the bare plen 'I have changed my mind' seriously."

The constructive trust operates to perfect the vendor's intention to pass the beneficial ownership of an asset to another. Having bargained away his options with respect to that asset, the vendor is not permitted, in equity, to change his or her mind and pay damages instead. This is a difficult argument and one which readers should explore for themselves. However, it is clear that the constructive trust in this situation is linked directly to the vendor's intention to confer a benefit on another. It cannot be explained as a response either to wrongdoing or to unjust enrichment. It is also clear that this is a primary use of the constructive trust. As discussed in the next sections, it is just one of many situations in which an intention to benefit another is the key ingredient calling for equity's intervention by way of constructive trust.

\section{SeCret Trusts}

A secret trust arises when the secret trustee receives an asset from the deceased settlor's estate, having agreed to use that asset for the benefit of another (the secret trust beneficiary). It is called a secret trust because the identity of the beneficiary of that trust does not appear in the settlor's last will and testament. It is clear that a secret trust is constructive. It takes effect on the death of the settlor and, being testamentary, could not be valid as an express trust unless it satisfied the formalities required by the Statute of Frauds 1677 or the various Wills Acts which have descended from it. Normally, a testamentary trust must be made in writing and signed by the settlor in the presence of two witnesses.

A difficult question is why equity imposes a constructive trust which has the effect of allowing the settlor to avoid statutory requirements regarding formalities. Attempts 
have been made to explain the secret trust as either restitution of unjust enrichment or restitution for wrongs. Neither approach is satisfactory. First, it is clear that secret trustees would be unjustly enriched if they were permitted to retain the beneficial ownership of the secret trust assets for themselves. However, this does not explain why the beneficial ownership of those assets is carried forward 10 the secret trust beneficiaries. As Professor Waters states:

[A] constructive trust imposed to prevent the unjust enrichment of the promisec should result in the promisec being ordered to restore the property to the deceased's eslate. To prevent unjust enrichment there is no need to compel the promisee to hold the property for the objects the deceased communicated to him. ${ }^{\text {is }}$

The unjust enrichment cannot explain the secret trust because the assets subject to that trust are obtained, not at the expense of the secret trust beneficiary, but at the expense of the settlor's estate. There would be an expense (i.e., corresponding deprivation) to the intended beneficiary if he or she had an enforceable right to receive them, ${ }^{69}$ but that presupposes that the settlor's intention to confer a benefit on the beneficiary has been effective to create a trust.

The proper restitutionary response in this situation would be to return the assets to the estate by way of a resulting trust. This is indeed what happens when a settlor fails to comply with the formalities required for an express inter vivos trust or when the minimal requirements of a secret trust are not met. A secret trust requires that the terms of the trust are communicated to the secret trustee before the settlor's death. In $R e$ Boyes, ${ }^{70}$ the objects of the intended secret trust were set out in letters found among the settlor's possessions after his death. Although the intended secret trustee wished to carry out the secret trust, he was required to hold the assets on resulting trust for the settlor's estate. Evidence of the intention to create a secret trust showed that the intended secret trustee was not intended to enjoy those assets for his own benefit and would be unjustly enriched if he were permitted to retain them. This produced a resulting trust, but more was needed before a constructive trust for the intended beneficiary was possible.

The second approach is to treat secret trusts as cases of restitution for wrongs. For example, in Jankowski v. Pelek Estate, Huband J.A. said, "The court will enforce the trust in order to avoid the fraud on the part of the legatee were he to keep the legacy as his own in defiance of his undertaking."'11 However, this suffers from the same inadequacies as the approach based on unjust enrichment. A secret trustee cannot be guilty of a breach of duty to the intended beneficiary unless there is a duty to use the (Boston: Little, Brown and Company. 1989) s. 55.1; Restatement of Restifution, supra note 21 at 758.

See Burrows, Restitution, supra note 12 at 45.54; L.D. Smith, "Three-Party Restitution: a Critique of Birks's Theory of Interceptive Subtraction" (1991) II O.J.L.S. 481; cf. Birks, Introduction. supra note 18 at 64-65, 135-36.

I" (1884), 26 Ch. D. 531.

$" \quad$ (1995), 131 D.L.R. (4th) 717 at 730 (Man. C.A.). 
secret trust assets for that person's benefit. In other words, the wrong depends on the existence of a constructive trust for the beneficiary according to the settlor's intentions. Without that trust it is impossible to identify the intended beneficiary as the victim of secret trustee's wrong. Otherwise, any breach of duty is to the settlor and a restitutionary response to that breach should produce a constructive trust for the settlor's estate. Also, there are cases, like Re Boyes, where the secret trustee desires to carry out the secret trust and is merely seeking the court's direction. It cannot be said that such a trustee is in breach of duty.

Both explanations of the secret trust, as either restitution of unjust enrichment or restitution for wrongs, presuppose the existence of an enforceable duty to use the secret trust assets for the intended beneficiary. It is simply not possible to make the creation of a constructive trust dependent on its own existence. ${ }^{72}$ The intended beneficiary's only connection to the secret trust assets is the settlor's intention that those assets be used for the beneficiary's benefit. That intention is central to the creation of the constructive trust in this situation.

Why does the law give effect to the settlor's intention to benefit another when that intention has not been manifested in compliance with the statutory requirements for a valid testamentary express trust? There is present an additional element beyond the mere intention to create a trust: the settlor's detrimental reliance on the secret trustee's promise to carry out the trust. As Professors Oosterhoff and Gillese say, "What is surely the basis of these trusts is the fact that the deceased has relied to his or her detriment upon the intended trustee's acceptance of the trust and died in the expectation that his or her wishes would be carried out." Where an express imer vivos trust fails, restitution by way of resulting trust is an appropriate response. At a minimum, it prevents the unjust enrichment of the intended express trustee and, if the settlor is alive and competent, he or she can choose to perfect the failed intention to benefit another. Perfection by the settlor is not possible in cases of secret trusts. Although a resulting trust for the settlor's estate would reverse the unjust enrichment of the secret trustee, it would ultimately defeat the settlor's intention to benefit the secret trust beneficiary. Therefore, the law imposes instead a constructive trust designed to perfect that intention.

The additional element of detrimental reliance appears to be a sufficient reason for ignoring statutory requirements regarding writing and witnesses. A bare intention to benefit another can take effect as an express trust, provided it is manifested with the appropriate formalities. That same intention, though expressed informally, can be given effect as a constructive trust so long as it coupled with a sufficient degree of detrimental reliance. Without reliance and detriment, there is insufficient reason for equity to intervene by perfecting an otherwise ineffective intention. This is perhaps why the secret trust in Re Boyes was not perfected. A settlor who does not communicate the

" See Oakley, supra note 49 at 248.

" Siupra note 43 at 498 . See Blackwell v. Blackwell, [1929] A.C. 318 at 329. [1929] All E.R. Rep. 73 at 74.75 . 
terms of the trust to the secret trustee during life cannot be said to be relying on the trustee's undertaking to carry out that trust.

The constructive trust which arises in this situation is very similar, if not identical to, the secret trust which the settlor intended to create, but expressed only informally. This has led many observers to regard the secret trust as nothing other than a blatant disregard of the formalities required by statute. If the secret trust had been manifested in writing and signed by the settlor in the presence of two witnesses, it would have taken effect as a testamentary express trust. Why should it be effective as a constructive trust without those formalities?

The source of the objection to secret trusts is that: (a) the intention to benefit another is almost, but not quite, the event which produces a testamentary express trust and yet (b) the constructive trust which arises is the same as express trust which was almost, but not quite, produced. However, the similarity to a failed express trust should not detract from the legitimacy of the perfectionary constructive trust as a response to an intersecting, but different category of events. The same concern does not arise when a contract of sale produces a constructive trust, because (a) the intention to benefit the purchaser, by formal inter vivos transfer of title, is clearly not an intention to create a trust and (b) the constructive trust which arises prior to transfer clearly differs from the legal ownership which the purchaser is intended to receive. Yet, in both these situations, the constructive trust is responding to the same type of event: an intention to benefit another coupled with some justification for perfecting that intention (either detrimental reliance or valuable consideration given in exchange). In neither case is the constructive trust a direct response to a bare intention to create a trust (which is only effective when expressed with appropriate formality).

The same concern about formalities was faced in connection with a resulting trust in Hodgson v. Marks. ${ }^{74}$ The plaintiff in that case had transferred her house to a rogue under an oral agreement that he would hold the land in trust for her. Instead, he sold the land to the defendant, who purchased the land in good faith, but subject to the plaintiff's interest (which had priority under the Land Registration Act 1925). The defendant argued that the plaintiff had attempted to create an express trust for herself and failed, because it was not manifested in writing as required by subsection 53(1) of the English Law of Property $\mathrm{ACt}$ 1925, and that this precluded an identical resulting trust arising in her favour. The Court of Appeal rejected this argument, recognizing that express and resulting trusts are created by different events:

[T] he evidence is clear that the transfer was not intended to operate as a gif, and, in those circumstances, I do not sce why there was not a resulting trust of the beneficial interest to the plaintiff, which would not, of course, be affected by section $53(1)$. It was argued that a resulting trust is based upon implied intention, and that where there is an express trust for the transferor intended and declared - albeit ineffectively - there is no room for such an implication. I do not accept that. If an attempled express trust fails, that seems to me just the occasion for implication of a resulting trust, whether the failure be due to uncertainty, or perpetuity, or lack of form. It would be a strange outcome if the 
plaintiff were to lose her beneficial interest because her evidence had not been confined to negativing a gift but had additionally moved into the field forbidden by section $53(1)$ for lack of writing."

Similar reasoning applies to secret trusts. The essential question is whether there exists, among the facts of a particular case, an event which gives rise to a constructive trust. Normally, it should not matter whether those facts are similar to the event which creates an express trust or some other right. One must say "normally," because there will be cases where an express trust or other right is defeated by some factor which should have the same effect on a constructive trust. For example, if an express trust failed because it was intended for an illegal purpose, a constructive trust should not be imposed if it would achieve that purpose. In such cases, it is not the presence of a failed express trust which defeats the constructive trust, but the wider application of the factor which caused the express trust to fail.

A common reason for the failure of an intended express trust is lack of compliance with the formalities required for its creation. The statutory requirement that express trusts be manifest in writing is never applied to resulting and constructive trusts. The Statute of Frauds 1677 and its descendants expressly exempt resulting and constructive trusts from that requirement. Therefore, the presence of an informally expressed and ineffective intention to create a trust should never interfere with the creation of a trust by operation of law.

\section{Mutual Wills}

Mutual wills are created when two people (usually husband and wife) promise each other not to revoke their wills. Typically, the mutual wills provide that the estate of the first to die will go to the survivor, whose estate will go to a common set of beneficiaries. They are free to revoke their wills until the first dies with the mutual will in force. The agreement between them then binds the survivor. If the survivor revokes the mutual will and disposes of his or her estate in a manner which conflicts with that will, his or her executors (or administrators) will hold the assets of the estate on constructive trust for the beneficiaries named in the mutual will. ${ }^{76}$

The constructive trust is used to perfect the survivor's promise to the deceased to confer a benefit on the beneficiaries of the mutual will. In most cases, the survivor promised to leave his or her estate, whatever it may be, to those beneficiaries. This is a promise to make a testamentary disposition. The subject matter of that promise is not known until the death of the survivor, which is when the constructive trust arises. ${ }^{77}$ There are a few cases in which the survivor promised to transfer a specific asset to the beneficiaries. In these, the constructive trust of that asset arises during the survivor's life, with the beneficial ownership of that asset belonging to the survivor for life and 670 at 676; T.G. Youdan, "The Mutual Wills Doctrine" (1979) 29 U.T.L.J. 390 at 410-14. 
the remainder to the beneficiaries. ${ }^{78}$ As with contracts of sale and secret trusts, the constructive trust in these situations cannot be explained as restitution in response either to unjust enrichment or to a breach of duty.

First, it is difficult to identify any unjust enrichment to which the constructive trust might respond. The executors are not unjustly enriched. They do not purport to retain the estate assets for their own benefit, but merely seek to distribute the estate according to law. If assets from the survivor's estate were distributed to persons other than the beneficiaries named in the mutual will, the recipients might be regarded as unjustly enriched, but only because the beneficiaries named in the mutual will have a better right to those assets (i.e., there is a pre-existing enforceable constructive trust in their favour). That unjust enrichment is not the source of the constructive trust, but is caused by a distribution of the estate contrary to the constructive trust, which arose independently in response to another event.

If the surviving testator is unjustly enriched, it is not at the expense of the beneficiaries of the mutual will. Their only claim to receive the assets of his or her estate is the promise made to the other testator. Any unjust enrichment of the surviving testator must be at the expense of the first testator to die. It is possible to construct an argument that the assets received by the survivor from the first to die ought to be restored to the estate of the latter (possibly on the basis of failure of consideration) and then distributed according to the mutual will, with the survivor excluded. Although this might be viewed as restitution of unjust enrichment, this is not how mutual wills operate. The constructive trust attaches to the assets of the survivor's estate, whether or not those assets were received under the mutual will of the first to die. ${ }^{79}$ The subject matter and objects of that constructive trust are defined by the survivor's promise, not by unjust enrichment.

In University of Manitoba v. Sanderson Estate, ${ }^{80}$ a husband and wife had made mutual wills in favour of the survivor and otherwise to the University of Manitoba. The wife died first, but her will was not probated. Most of her assets were owned jointly with the husband, who acquired them by way of survivorship and not as the beneficiary of her will. He changed his will, died, and the beneficiaries under the new will argued that, since he had not been unjustly enriched at the expense of his wife, there could be no constructive trust for the university. Rowles J.A. said:

[T] he trial judge erred when he concluded that an unjust enrichment was required. A constructive trust arising from an unjust enrichment is imposed on property gained at the expense of another for no juristic reason, whereas the obligation created by an agreement not to revoke mutual wills binds not Mansfield, [1997] 2 N.Z.L.R. 230.

79 Re Dale, [1993] 4 All E.R. 129 at 137; University of Manitoba v. Sanderson Estate, supra note 76. 
only that portion of the survivor's estate which may have come from the estate of the first to die, but also his or her own property."

The second approach to mutual wills, as restitution in response to a breach of duty by the surviving testator, suffers from similar difficulties. The beneficiaries named in the mutual wills cannot identify themselves as victims of a breach of duty unless they have an enforceable right to receive the assets in question (i.e., the constructive trust must already exist independently of the breach). The executors are not in breach of duty, but merely seeking to administer the estate properly. Other recipients of assets from the survivor's estate would be under a duty to make restitution of any assets properly belonging to the beneficiaries under the mutual will, but the mere receipt of those assets cannot be a wrong.

The only duty breached is the survivor's promise to the other testator. The response to that breach is not restitution, but specific enforcement of the duty breached. In other words, the constructive trust arises to perfect the survivor's intention to benefit the beneficiaries of the mutual will. In any event, a breach of contract is not normally considered a wrong for which restitution is available. ${ }^{82}$ It is sometimes suggested that the constructive trust is triggered by the survivor's fraud. In University of Manitoba $v$. Sanderson Estate, Rowles J.A. stated:

Equity considers it a fraud upon the deceased, who has acted upon and relied upon the mutually binding nature of the agreement, for the survivor to change the will and break the agreement. As the deceased cannol intervene to enforee the obligation, equity will enforce the survivor's obligation, despile the survivor's subsequent intentions."

If the constructive trust is a response to fraud, the response is perfectionary, not restitutionary. ${ }^{84}$ It is not restitution to the victim, of assets received through the fraud, but enforcement of the promised performance. In any event, fraud is not required for the creation of a constructive trust in this situation. In most cases, the mutual wills will be made by parties honestly intending to fulfil their promises when the time comes. However, subsequent events may cause the survivor to change his or her mind or the agreement may be breached unintentionally by a survivor who remarries and dies without realising that the marriage revoked the mutual will.85 If these failures to keep promises honestly made are fraudulent, then so is every breach of contract. ${ }^{86}$

A worthy justification for equity's intervention can be seen in the quotation from University of Manitoba v. Sanderson Estate, above. As Rowles J.A. said, the first testator to die "has acted upon and relied upon" the survivor's promise to make a

lbid. at 57.

Sec supra note 13.

Supra note 76. Also sec Re Dale, supra note 79.

Cf. C.E.F. Rickett, "Mutual Wills and the Law of Restitution" (1989) 105 L.Q.R. 534 at 538-39;

C.E.F. Rickett, "Mutual Wills, Restitution and Constructive Trusts Again" [1996] Conveyancer

136 at 141.

See Youdan, supra note 77 al 405.

Ibid. at 400-401. 
testamentary disposition in favour of agreed beneficiaries. Alternative arrangements might have been made if he or she had known that the promise would not be kept. This final act of detrimental reliance justifies intervention through the creation of a constructive trust designed to perfect the survivor's intention to benefit the beneficiaries as agreed.

\section{E. INCOMPLETE GIFTS}

Equity's treatment of incomplete gifts is anomalous. When a donor has done everything he or she needs to do to make a gift, and the donee has the power to take the extra steps needed to cause legal title to pass, equity treats the gift as complete. ${ }^{87}$ Although legal title has not yet passed to the donee, equitable beneficial ownership has. This separation of legal and beneficial ownership by operation of law is, by definition, a constructive trust. The event creating that trust is plain: an intention to make a gift, coupled with actions which empower the donee to complete the gift.

The difficult question is why the constructive trust arises. There is no consideration from, or detrimental reliance by, the donee. The usual reasons for equitable intervention are missing. It is true that there is no need to compel the donor to do anything to perfect the gift. However, the gift becomes irrevocable at the moment the constructive trust arises. ${ }^{88}$ It is odd that a donor with legal title can be prevented from enjoying the full benefit of that right by an intended donee who has not suffered detriment in reliance on the expected gift. However, as Browne-Wilkinson L.J. pointed out in Mascall v. Mascall, ${ }^{\text {g9 }}$ the donor who changes his or her mind requires the assistance of a court of equity to recover the documents which enable the donee to perfect the gift. There is no reason for equity to intervene with the donee's ownership of those documents, which were freely given by the donor.

According to the Restatement of the Law of Restitution, in American law, the constructive trust of an incomplete gift arises only "if the donor dies believing that he had made an effective gift" or "the donee so changes his position in reliance upon the gift that it would be inequitable to preclude him from obtaining the property." ${ }^{10}$ In other words, there is some detrimental reliance either by the donor or by the donee. There do not appear to be any such restrictions in Canadian, English, or Australian law.

Dr. Elias explains equity's intervention in this situation as respect for the autonomy of the donor's choice to dispose of his or her options in favour of the donee. ${ }^{91}$ That commitment is made when the donor gives the donee the power to obtain legal title, at which point, equity treats the decision as binding. 
In any event, it can be said that, in at least one important respect, an incomplete gift lines up with other events giving rise to constructive trusts. As a general rule, if a plaintiff in a court of equity can compel the defendant to transfer an asset, the plaintiff is regarded as the owner of that asset in equity. ${ }^{92}$ The donee of an incomplete gift is in a similar position except that he or she does not need the assistance of equity, but can complete the transfer of legal title through self help. A purchaser who can obtain an order for specific performance and a donee who can achieve the same end by other means are both regarded by courts of equity as owners of the assets within their power.

However the constructive trust of an incomplete gift is explained, it is clear that this trust arises, in the absence of breach of duty or unjust enrichment, to perfect the donor's intention to benefit another. ${ }^{93}$

\section{F. FAMILY PROPERTY}

This part of the essay concerns the use of the constructive trust to distribute assets between married or de facto spouses on the breakdown of their relationships. The Supreme Court of Canada has stated clearly on several occasions that the event giving rise to the constructive trust in this situation is unjust enrichment. Indeed, the Canadian link between unjust enrichment and constructive trust was forged in this context. Nothing could be plainer than Dickson J's statement in Pettkus v. Becker that, "The principle of unjust enrichment lies at the heart of the constructive trust." 94 Although it will no doubt be controversial, the purpose of what follows is to show that the constructive trust in this situation is not restitutionary, but perfectionary. It is raised to give effect to detrimentally relied upon expectations concerning ownership of the family home.

When Pettkus v. Becker was decided, the Supreme Court of Canada was seeking a solution to the difficult problem of dividing assets between two people who have decided to go their separate ways following a period of cohabitation. Much of the wealth built up during the course of their relationship may be tied up in their family home and title to that land may be held by one of them (the defendant). If the other party (the plaintiff) is entitled to a share of the home, it must be a trust. An express trust is unlikely, since an intention to create that trust must be manifested in writing. A resulting trust is possible if the plaintiff contributed to the defendant's acquisition of the home. However, the defendant may have acquired the home before the relationship began, the plaintiff's income may have been spent on other things, or the plaintiff may have contributed to the relationship in other ways, such as caring for children or keeping house. Therefore, in many cases, the plaintiff's right to a beneficial share of the home will only be possible as a constructive trust.

See, e.g., A-G Hong Kong v. Reid, supra note 34.

" D.J. Hayton, "Constructive Trusts: Is the Remedying of Unjust Enrichment a Satisfactory Approach?" in T.G. Youdan, ed., Equin. Fiduciaries and Trusts (Toronto: Carswell, 1989) 205 at 212 . 
Courts in many jurisdictions wrestled with the difficult task of identifying an event which justified the imposition of a constructive trust over the family home. The Supreme Court of Canada was unhappy with the direction taken in England, where a constructive trust of a family home is based upon the "common intention" of the parties. ${ }^{95}$ In Rathwell v. Rathwell ${ }^{36}$ and Pettkus v. Becker, ${ }^{97}$ the Canadian court turned to unjust enrichment as a substitute.

It is true that unjust enrichment is often present in these cases. The plaintiff has provided assets or services to the defendant on the basis that those benefits will be used for the betterment of both parties as a family. The end of the relationship was not contemplated and it was not intended that the defendant should have the use and enjoyment of those benefits to the exclusion of the plaintiff. It is the failure of the purpose for which the benefits were provided (i.e., failure of consideration) which renders the enrichment unjust. ${ }^{98}$ To borrow the words of Deane J. of the High Court of Australia, these are cases "where the substratum of a joint relationship or endeavour is removed without attributable blame and where the benefit of money or other property contributed by one party on the basis and for the purposes of the relationship or endeavour would otherwise be enjoyed by the other party in circumstances in which it was not specifically intended or specially provided that that other party should so enjoy it." 99 However, as discussed above in connection with the secret trust, the presence of unjust enrichment does not necessarily mean that the constructive trust is responding to that unjust enrichment.

\section{RESPONSES TO UNJUST ENRICHMENT}

Unjust enrichment is capable of generating only one type of response: restitution of that unjust enrichment or its value in money. Absent a promise or breach of duty, there is no justification for doing anything other than removing the benefit from the defendant. The liability is created solely by the receipt of a benefit which the law regards as reversible and that liability can be nothing other than to give up a thing received at the plaintiff's expense or its value in money.

Giving up an asset received at the plaintiff's expense is the least intrusive method of restitution. It removes that asset from the defendant, whatever its value, and does not require the defendant to use other resources to fulfil the duty to make restitution. ${ }^{100}$ Restitution through payment of the value of the benefit received is more difficult. It may be that the defendant did not want the benefit (at all or at its market price) or that the benefit was dissipated without benefit to the defendant. This is why the law of unjust enrichment is concerned with questions such as whether the enrichment was an 
"incontrovertible benefit" to the defendant, ${ }^{101}$ whether the defendant can "subjectively devalue" the benefit of the enrichment, ${ }^{102}$ and whether the enrichment has been lost or diminished through the defendant's "change of position." 103

Unjust enrichment, by itself, never justifies giving the plaintiff a property right to one of the defendant's other assets, even if the value of that property right coincidentally equals the value of the unjust enrichment. For example, suppose that I pay you $\$ 27,000$ by mistake and have a personal right to restitution of that unjust enrichment (by repayment of that sum as money had and received). Suppose further that you have a cabin at the lake worth $\$ 27,000$. Can your unjust enrichment at my expense give me a property right to your cabin? It may be possible if I can trace the value of my money to your cabin. If you used that value to purchase the cabin, I might claim a resulting trust. ${ }^{104}$ If you used it to improve the cabin or reduce a mortgage of it, I might have an equitable lien. ${ }^{105}$ These are property rights generated by unjust enrichment, but they depend on proof that the value of the unjust enrichment initially received at my expense traceably survives in your cabin.

Unless an unjust enrichment continues to exist as all or part of the value of an asset in the defendant's hands, there is no justification for creating a property right to effect restitution of that unjust enrichment. There is simply no connection between the unjust enrichment and the defendant's assets and no reason why one asset should be chosen, in preference to any other, to satisfy the obligation to make restitution. The same is true of other obligations, such as payments due under a contract or to compensate for losses caused by a tort. The creation of a property right requires justification and unrelated indebtedness will not do. As Professor Birks said:

A judgment for the surrender of items of propeny inllicts loss, as does a money judgment, but, unlike a money judgment, also entangles itself in the complexities both of unwanted consequences for third parties and of individual economic priorities. The latter point is important and often neglected. Taking money from people makes them worse off and narrows their options, taking specific things is a more erratic instrument of justice, because of their subjective value: the same 'adjustment' will cause vastly different degres of pain, depending on the sentiments and tastes of the loser. ${ }^{\text {uro }}$

Peel (RM) v. The Queen, [1992] 3 S.C.R. 762, 98 D.L.R. (4th) 140; M. Mclnnes, "Incontrovertible Benefits in the Supreme Court of Canada" (1994) 23 Can. Bus L.J. 122.

so2 P. Birks, "In Defence of Free Acceptance" in Burrows, ed., supra note 36, 105 at 127-43 [hercinafter Birks, "In Defence of Free Acceptance"]; see Republic Resources Lid. v. Ballem, [1982] I W.W.R. 692, 17 Alta. L.R. (2d) 235 (Q.B.). "Change of Position" in P. Birks, ed., Laundering and Tracing (Oxford: Clarendon Press, 1995) at 135; P. Birks, "Change of Position: the Nature of the Defence and its Relationship to Other Restitutionary Defences" in M. Mclnnes, ed., Restifution: Developments in Unjust Enrichment (Sydncy: LBC Information Services, 1996) 49. L.D. Smith. The Law of Tracing (Oxford: Clarendon Press, 1997) at 294-95, 357-58 [hereinafter Smith, The Law of Tracingl. 
To return to our cabin example, you might attach particular sentimental value to that cabin and much prefer to give up $\$ 27,000$ from your bank account or some other source than lose the cabin. My claim for restitution of unjust enrichment should not interfere with that choice unless the cabin is that unjust enrichment. It is true that an unsatisfied judgment for that $\$ 27,000$ might lead to the seizure and sale of the cabin, but that right is created not directly by unjust enrichment, but by the general law which allows for execution in satisfaction of judgment debts, whatever their provenance. Liability for execution is a general and justifiable limitation on the enjoyment of property. ${ }^{107}$

It is possible to generate a property right in the cabin by changing the facts of our example. Suppose instead that I pay you $\$ 27,000$ with the expectation of receiving an interest in the cabin. If you promised to transfer the cabin to me in exchange for my payment and that promise was specifically enforceable, the cabin would be held on constructive trust for me. However, as discussed above, that trust is created, not by the payment, but by the promise. It is perfectionary, not restitutionary. Your choice to dispose of the cabin justifies the creation of my property right.

Unless modified by statute, the law in family property cases is the same as in other situations. ${ }^{108}$ The application of legal rules to different facts may produce different legal responses, but the rules do not change as the threshold of the family home is crossed. Where one spouse has been unjustly enriched at the expense of the other, there are three possible restitutionary responses, depending on the nature of the enrichment. One is a money judgment for the value of the benefit received. ${ }^{109}$ Another is a resulting trust of an asset where that asset was acquired by one spouse at the expense of the other. ${ }^{110}$ The third is an equitable lien on an asset for the value of improvements to that asset or the reduction of a mortgage or other security interest over that asset. "I'

In Canada, the constructive trust is regarded as the primary response to unjust enrichment in family property situations. However, it is clear that the trust can attach to assets other than those received at the expense of the other spouse. ${ }^{112}$ The presence of unjust enrichment in the family relationship cannot explain this response. ${ }^{113}$ The constructive trust in this situation is like the secret trust discussed above: the constructive trustee has been unjustly enriched, but the constructive trust is not a

Honoré, supra note 65 at 123-24.

Peter v. Beblow, [1993] 1 S.C.R. 980, 101 D.L.R. (4th) 621 at 649-50 (hereinafter Peser v. Beblow cited to D.L.R.]; Gissing v. Gissing, [1971] A.C. 886, [1970] 2 All E.R. 780 at 789 [hereinafter Gissing v. Gissing cited to All E.R.]; Grant v. Edwards, [1986] Ch. 638, 2 All E.R. 426 at 435. Peter v. Beblow, ibid. at 649; see P. Parkinson, "Beyond Pettkus v. Becker. Quantifying Relief for Unjust Enrichment" (1993) 43 U.T.L.J. 217.

Goodfriend v. Goodfriend, [1972] S.C.R. 640, 22 D.L.R. (3d) 699; MacPherson v. MacPherson (1971), 5 R.F.L. 158; Calverley v. Green (1984), 155 C.L.R. 242, 56 A.L.R. 483 [hercinafter Calverley v. Green cited to C.L.R.J.

Calverley v. Green, ibid.

Sorochan v. Sorochan, [1986] 2 S.C.R. 35, 29 D.L.R. (4th) I [hereinafter Sorochan cited to D.L.R.]; Peter v. Beblow, supra note 108.

See R.E. Scane, "Relationships 'Tantamount to Spousal', Unjust Enrichment, and Constructive Trusts" (1991) 70 Can. Bar Rev. 260 at 291, 305. 
response to that enrichment. In secret trust cases, the unjust enrichment is the subject of the trust, but the trust does not return that enrichment to the person at whose expense it was obtained. In family property cases, the beneficiary of the constructive trust is the person who suffered the corresponding deprivation, but the asset subject to that trust is not the asset or benefit which constitutes the unjust enrichment.

\section{DEtrimental RELIANCE ON EXPECTATIONS}

What then is the event to which the constructive trust is responding? Like the secret trust, the constructive trust of a family home is imposed to perfect a detrimentally relied upon expectation regarding the beneficial ownership of that home. As Dickson J. said in Pettkus v. Becker:

[W] here one person in a relationship tantamount to spousal prejudices herself in the reasonable expectation of receiving an interest in property and the other person in the relationship freely accepts benefits conferred by the first person in circumstances where he knows or ought to have known of that reasonable expectation, it would be unjust to allow the recipient of the benefit to retain it."14

This was confirmed in Sorochan v. Sorochan, where Dickson C.J. said:

[I]n assessing whether a constructive trust remedy is appropriate, we must direct our minds to the specific question of whether the claimant reasonably expected to receive an actual interest in property and whether the respondent was or reasonably ought to have been cognizant of that expectation. "Is

Detrimental reliance on an expectation regarding beneficial ownership of an asset can justify the creation of a constructive trust of that asset. It generates constructive trusts in other situations, such as secret trusts and mutual wills, discussed above, and in response to events sometimes described as "proprietary estoppel."16 However, the trusts in those situations are perfectionary, not restitutionary. Although the presence of unjust enrichment may be a reason for perfecting intentions regarding the ownership of the family home, this does not mean that the constructive trust is a response to that unjust enrichment. The trust is not possible unless the constructive trustee is (or ought to be) aware that the beneficiary expected to receive an interest in the assets subject to that trust. That expectation is the key ingredient and the constructive trust arises to perfect it. This is obscured in Canada by emphatic judicial assertions to the contrary, but has been observed from overseas. ${ }^{117}$ As Dr. Elias states:

[T]he U.S.A. insistence that constructive trusts are generally restitutionary is understandable in the light of their range of pertinent rules. In contrast, the new Canadian view that constructive trusts are restitutionary is puzzling. The new Canadian view became established in Pettkus v. Becker (1980)....

Supra note 20 at 274.

Supra note 112 at 12.

See Dilluyn v. Llewellyn (1862), 4 De GF\&J 517, 45 E.R. 1285, [1861-73] All E.R. Rep. 384; Re

Basham, [1987] I All E.R. 405 at 410; Zelmer v. Victor Projects Lid. (1997), 147 D.L.R. (4th) 216 (B.C.C.A.); Elias, supra note 2 at 56-58.

Gillies v. Keogh, [1989] 2 N.Z.L.R 327 at 333 (C.A.); Burrows, Restinution, supra note 12 at 38. 
The majority in effect took the ... view that the trust in issue was not perfectionary and could therefore arise irrespective of the wishes of the parties. This view is simply nol quite true. The trust which was found in Pettkus was very much perfectionary in spite of the majority's insistence to the contrary. ${ }^{\text {"I }}$

What led the Supreme Court of Canada to adopt unjust enrichment as an explanation of the constructive trust of the family home? As mentioned above, the English courts based the constructive trust in this setting on the detrimentally relied upon common intention of the parties. Dickson J. was dissatisfied with "the judicial quest for that fugitive common intention,"119 since, in many cases, the parties never reached an express agreement on the distribution of the beneficial ownership of the home. The defendant's unjust enrichment at the plaintiff's expense provided a justification for perfecting the reasonable expectation of the plaintiff, even in the absence of such an agreement.

The seeds for a similar development in England were present in Gissing v. Gissing, where Lord Diplock said:

As in so many branches of English law in which legal rights and obligations depend upon the intentions of the partics to a transaction, the relevant intention of each party is the intention which was reasonably understood by the other party to be manifested by that party's words or conduct notwithstanding that he did not consciously formulate that intention in his own mind or even acted with some different intention which he did not communicate to the other party. ${ }^{120}$

This level of common intention is very close to the reasonable expectation which will give rise to a constructive trust in Canada. Indeed, in Gissing v. Gissing, Lord Diplock said that a constructive trust of a family home would be possible "if by his words or conduct [the constructive trustee] has induced the cestui que trust to act to his own detriment in the reasonable belief that by so acting he was acquiring a beneficial interest in the land."'21 However, the English requirement of a common intention, rather than a reasonable expectation, has caused the constructive trust of the family home to develop at a slower pace there than in Canada.

In Gillies v. Keogh, ${ }^{122}$ the New Zealand Court of Appeal set the constructive trust of a family home firmly on a foundation of detrimentally relied upon expectations. After an examination of the approaches used in Canada, Australia, and England, Cooke P. said, "The practical position now reached in de facto union cases by all the various routes appears to me that the Courts have regard to the reasonable expectations of persons in the shoes of the respective parties." ${ }^{23} \mathrm{He}$, and the other members of the court, linked this approach to estoppel. Richardson J. said:

Elias, supra note 2 at 157.

Pettkus v. Becker, supra note 20 at 269.

Supra note 108 at 790; also set Calverley v. Green, supra note 110 at 261.

lbid. at 790; see S. Gardner, "Rethinking Family Property" (1993) 109 L.Q.R. 263 at 266-69.

Supra note 117.

Ibid. at 333. 
[W] ith some limitations, the doctrine of estoppel provides an appropriately principled approach, short of legislation, to the resolution of property disputes arising on breakdown of de facto relationships in cases where the parties have not dealt expressly with the matter, and an actual common intention cannot be discemed. The three elements, encouragement (of a belief or expectation), seliance and detriment have to be considered in the light of the actual relationship of the parties, the way they lived their lives. ${ }^{124}$

What distinguishes New Zealand's approach from those taken in Canada, Australia, and England, is its transparency. In all four countries, the constructive trust of a family home can respond to detrimental reliance on a reasonable expectation of receiving a beneficial interest in that home. However, in Canada, Australia, and England, that is obscured by the language of unjust enrichment, unconscionability, or common intention.

\section{THE ROLE OF UNJUST ENRICHMENT}

If it is recognized that it is the detrimentally relied-upon expectation, and not unjust enrichment, which lies at the heart of the constructive trust of the family home, then two questions need to be answered: (a) should recovery by way of constructive trust be limited to the net value of the unjust enrichment provided by the plaintiff to the defendant and (b) is unjust enrichment needed at all?

First, the unjust enrichment of the defendant at the expense of the plaintiff does not give rise to the constructive trust directly, but is the reason for perfecting the plaintiff's reasonable expectation of receiving an interest in the family home. As Dickson J. said, by conferring the unjust enrichment on the defendant, the plaintiff "prejudices herself in the reasonable expectation of receiving an interest in the property." 25 In other words, the unjust enrichment fulfils the role that detriment plays in similar areas of law, such as secret trusts, mutual wills, and estoppel. While a restitutionary response to unjust enrichment (e.g., a resulting trust) is necessarily measured by the value of that enrichment, the constructive trust of the family home arises to perfect an intention and, therefore, does not have to correspond to the value of the unjust enrichment which justifies its creation.

Where a constructive trust of a family home is possible, there are three different values by which that trust could be measured: (a) the interest the plaintiff reasonably expects to receive, (b) the unjust enrichment of the defendant, or (c) the detriment to the plaintiff. The expectation should provide the upper limit. Since the constructive trust is not a direct response to the unjust enrichment, greater enrichment would not justify creating a constructive trust which exceeded the expectation. Of course, there may be an alternative claim for restitution of that unjust enrichment (e.g., by way of a resulting trust of that enrichment or a personal claim for its value). The same is true of the level of detriment. The constructive trust of the family home is not a response to wrongdoing and, therefore, should not be used to compensate the plaintiff for losses suffered above the value of the expected interest. Again, this does not rule out a claim for 
compensation for loss on some alternative basis (e.g., damages for intentionally or negligently causing physical injury).

There will be cases where the expectation exceeds the unjust enrichment of the defendant. Should the constructive trust in such cases be restricted to the value of the unjust enrichment? It is helpful to consider the example provided by Peter v. Beblow. ${ }^{126}$ The parties lived together for twelve years in a house which the defendant owned when they met. During their time together, the plaintiff cared for the defendant's children, looked after the house and garden, and provided other benefits to the defendant, such as shovelling snow and chopping wood. Those services were valued at $\$ 350$ per month for a total of $\$ 50,400$ over twelve years. This was reduced by half, to account for the value of benefits flowing the other way, such as the housing and food which the defendant provided for the plaintiff and her children, producing a net unjust enrichment to the defendant of $\$ 25,200$. The defendant's house was worth $\$ 23,200$, therefore its full value was held on constructive trust for the plaintiff. According to Cory J., this trust was justified because, "It could reasonably be inferred that given the work she had done, the [plaintiff] would expect to receive a share in the [house] when the relationship ended." 227

Although the value of the unjust enrichment exceeded the value of the constructive trust in Peter v. Beblow, there will be cases where the expectation exceeds the enrichment. What if the plaintiff had performed the same services over 12 years, but the defendant's house is valued at $\$ 232,000$ ? If the calculation in Peter v. Beblow is made using ten times the market value of the housing provided by the defendant, it appears that the plaintiff is unjustly enriched at the defendant's expense. It would be surprising indeed if a plaintiff, who made the same sacrifices as Ms. Peter in reliance on the same reasonable expectation of receiving a share in the family home, would not be entitled to a constructive trust if the benefits flowing from the defendant exceeded $\$ 350$ per month (bare subsistence in the eyes of many Canadians). Part of the difficulty may be the low market value placed on traditionally female labour, but the law of unjust enrichment must work with the market values given to it. It does not punish nor right the wrongs of the world. The most the law of unjust enrichment can do is require a defendant to give up a benefit received or its market value. ${ }^{128}$

In many family property cases, the desired outcome cannot be achieved either through restitution of unjust enrichment or through perfection of intention limited to the value of unjust enrichment. Receiving a share of the family home based on the market value of the plaintiff's contributions to the relationship may well be a poor return for the sacrifices and hopes of many years. A division of family property designed to reverse the parties' inputs is inadequate in such cases. This is recognized in other areas of law. Giving people their money back is, in many cases, just not good enough. For example, purchasers of a home will not be happy if, on moving day, the vendors say, "We're sorry. We've changed our minds. Here's your deposit." As discussed above, the

122 See Birks, "In Defence of Free Acceptance," supra note 102 at 128-34. 
law does not tolerate this and raises a constructive trust to perfect the intention to transfer beneficial ownership. A straight reversal of inputs may be an appropriate response to the breakup of some family relationships, such as those of short duration or where the parties maintained financial independence throughout. ${ }^{129}$ However, there are others in which that approach is unacceptable due to the presence of detrimentally relied upon expectations.

There are cases, like Peter v. Beblow, where the measure of unjust enrichment produces a rough justice because the market values of the parties' inputs into their relationship are roughly equivalent to the values of the shares of family assets they expected to receive. ${ }^{130}$ However, there will be many cases where there is great disparity between the market values of inputs and expectations. The total market value of the plaintiff's income and other contributions to the relationship might be a small fraction of those made by the defendant. This should not be used to devalue the reasonable expectations held, or sacrifices made, by the plaintiff. There is no necessary connection. Fortunately, the constructive trust in this situation is raised, not to effect restitution, but to perfect expectations regarding ownership of the family home. Therefore, it need not be limited to the value of the unjust enrichment.

This leads to the second question: is unjust enrichment needed at all? In this context, unjust enrichment is used to justify the creation of a perfectionary constructive trust, despite the lack of a clear, and properly manifested, intention to create such a trust. The unjust enrichment is evidence of the prejudice suffered in reliance on the reasonable expectation. However, there are many forms of prejudice. For example, the plaintiff may forego educational or career opportunities, bear and raise children or refrain from having children, move away from family and friends, or care for the families of others. A permanent, irreversible detriment might produce comparatively little or even no benefit for the defendant. Can a sufficient level of detriment take the place of unjust enrichment as a justification for the constructive trust?

In cases where a property right is created by estoppel, it is clear that detrimental reliance is a sufficient justification for perfecting the expectation in the absence of benefit to the defendant. ${ }^{131}$ In $R e$ Basham, ${ }^{132}$ Edward Nugee Q.C. noted the similarities among proprietary estoppel, secret trusts, mutual wills, and family property: all involve a constructive trust of an asset which is created by detrimental reliance on intentions regarding the use of that asset. He then said:

A common theme can be discerned in each of these classes of case; and although different situations may give rise to differences of detail in the manner in which the courts will give effect to the equity

Peter v. Beblow, supra note 108 at 640; see Parkinson, supra note 109; S. Gardner, supra note 121 at 289.95. 
which arises in favour of the [plaintif], one would expect the general principles applicable in the different situations to be the same unless there is a sound reason to the contrary. ${ }^{\text {"' }}$

Is there a sound reason why a benefit to the defendant should be required in family property cases? In New Zealand, it seems that, although a benefit to the defendant will usually exist, it is not essential. In Gillies v. Keogh, Cooke P. discussed the factors which the court takes into account when assessing the reasonable expectations of the parties. He said:

First, a major factor must be the degree of sacrifice by the claimant.... In de facto union cases often, though not always, the degree of sacrifice by one partner will be a guide to the measure of any unjust enrichment of the other.... One has to remember that sacrifice cannot always be measured in Jollars and cents. ${ }^{134}$

Although Cooke P. went on to say that "a second and equally obvious major factor to be weighed is the value of the broadly measurable contributions of the claimant by comparison with the value of the broadly measurable benefits received," this was expressly made subject to his comments regarding the claimant's sacrifice. ${ }^{135}$ Richardson J. said that the issue "involves determining whether the elements of encouragement (of a belief or expectation), reliance on that, and detriment were present."136 The plaintiff in Gillies v. Keogh had provided a significant benefit to the defendant, so there was no need to explore at greater length whether detriment without benefit would suffice.

In England, benefit to the defendant is used as evidence of the existence of a common intention to share the beneficial ownership of the home. In Lloyds Bank plc v. Rosset, Lord Bridge said that, "where there is no evidence to support a finding of an agreement or arrangement to share," it is possible "to infer a common intention to share the property beneficially" where the plaintiff contributed to the purchase price or mortgage payments. ${ }^{137}$ However, if the common intention is established, benefit to the defendant is not required. As Lord Bridge said:

Once a finding to this effect is made it will only be necessary for the partner asserting a claim to a beneficial interest against the partner entitled to the legal estate to show that he or she has acted to his or her dutriment or significantly allered his or her position in reliance on the agreement in order to give rise in a constructive trust or a proprictary estoppel.'"

In Canada and New Zealand, courts do not take this restrictive view of the necessary intention. A reasonable expectation will do and those expectations are, to some extent, a function of prevailing societal values. In Gillies v. Keogh, Richardson J. said: 
Whatever the position in other countries, it seems to me that social attitudes in New Zealand readily lead to expectations, by those within apparently stable and enduring de facto relationships, that family assets are ordinarily shared, not the exclusive property of one or the other, unless it is agreed otherwise or made plain."1"1

This is echoed in Peter v. Beblow, where Cory J. said:

In today's society it is unreasonable to assume that the presence of love automatically implies a gift of one party's services to another. Nor is it unreasonable for the party providing the domestic labour required to create a home to expect to share in the property of the parties when the relationship is terminated. ${ }^{121}$

Cory J. may be suggesting that the unjust enrichment of the defendant is part of the process which leads to the plaintiff's expectation of receiving an interest in the home. However, the reasonable expectations of Canadians at the end of the twentieth century have been shaped by Pettkus v. Becker. The expectation of sharing the beneficial ownership of the family home, which may have depended on unjust enrichment in the 1970 s and 1980s, might now be regarded as a normal feature of most stable family relationships. In any event, if it can otherwise be established that the plaintiff did expect to receive that interest, the defendant was or ought to have been aware of that expectation, and the plaintiff suffered significant detriment in reliance on that expectation, is unjust enrichment necessary? The justification for perfecting that intention exists without it.

\section{UNJUST ENRICHMENT}

This section on unjust enrichment may seem surprisingly short to a Canadian reader, who might expect that an essay entitled "Constructive Trusts in Canada" would be concerned with little else. However, as discussed above, most constructive trusts respond to events other than unjust enrichment. Once restitution for wrongs and perfection of intentions are removed, it is not clear what, if anything, remains.

The length of this section is not an indication of the importance of this subject. The creation of trusts to effect restitution of unjust enrichment involves a number of complex issues on which much work has been, and remains to be, done. However, there are good reasons to believe that this work does not involve the constructive trust. Two difficult questions are addressed in this section: (a) when does unjust enrichment give rise to a trust and (b) is the trust constructive or resulting? 


\section{A. When does Unjust Enrichment Give Rise to A Trust?}

There are a variety of responses to unjust enrichment of the defendant at the plaintiff's expense. All are designed to cause the defendant to give up to the plaintiff the enrichment itself or its value in money. The rights generated by unjust enrichment may be personal or proprietary and may be legal or equitable. An example of a common-law personal right to be paid the value of the unjust enrichment is the action for money had and received. ${ }^{141} \mathrm{~A}$ similar equitable personal right is the claim based on "knowing receipt" of an asset improperly transferred from a trust or company. ${ }^{142}$ Sometimes, unjust enrichments generate property rights (such as trusts, equitable liens, or rights to rescind or rectify transactions and recover title to an asset) ${ }^{143}$ or they may give rise to both personal and property rights. For example, a payment of money by mistake might give rise to an action for money had and received as well as a trust of that money or any asset into which it can be traced. ${ }^{144}$

Although there are many cases of trusts raised to effect restitution of unjust enrichment, it is not easy to work out from these cases why unjust enrichments only sometimes give rise to trusts. This is in marked contrast with many other areas of law in which the events which generate property rights are clearly understood. For example, it is well settled how one makes a declaration of trust, sale of goods, or mortgage of land. The creation of property rights by unjust enrichment deserves to be understood with the same degree of certainty. Although that is not yet possible, some guidelines can be suggested.

\section{MINIMUM REQUIREMENTS for A TRUST}

There are two minimum requirements which should be met before a trust is a possible response to unjust enrichment: (a) that the unjust enrichment is an asset capable of being the subject matter of a trust and (b) that the defendant did not acquire the full beneficial ownership of that asset before the plaintiff's right to restitution arose. $^{145}$

First, unjust enrichment cannot give rise to a trust unless that unjust enrichment is an asset capable of being the subject matter of a trust. As discussed above in connection with family property, the defendant's receipt of an unjust enrichment does

Birks, Introduction, supra note 18 at $78-80,111-13$; Maddaugh \& McCamus, supra note 13 at 68 72.

142 Burrows, Restitution, supra note 12 at 150-58; M. Bryan, "The Receipt-Based Constructive Trust" (1999) 37 Alta. L. Rev. 73.

141 R. Goff \& G. Jones, The Law of Restitution, 4th ed. (London: Sweet \& Maxwell, 1993) at 73.

144 Chase Manhaltan Bank NA v. Israel-British Bank (London) Lid., [1981] Ch. 105, [1979] 3 All E.R. 1025 thereinafter Chase Manhaulan Bank NA cited to All E.R.]; also see Re Diplock [1948] Ch. 465, [1948] 2 All E.R. 318 (C.A.); aft Ministry of Health v. Simpson, [19SI] A.C. 25I. [1950] 2 All E.R. 1137.

ius Millett, supra note 43 at 406; Chambers, Resulting Trusts, supra note 43 at 144-53; also see Birks, Introduction, supra note 18 at 378-79; R.M. Goode, "Ownership and Obligation in Commercial Transactions" (1987) 103 L.Q.R. 433 at 443; Goode, "Property and Unjust Enrichment" supra note 36 at 219. 
not justify the creation of property rights to other assets owned by the defendant. The trust depends on the continued existence of the unjust enrichment as an asset acquired at the plaintiff's expense, either directly or with value that can be traced from the plaintiff. This rules out the possibility of trusts raised in response to unjust enrichments which consist of pure services. Although services can be enriching and can generate personal rights to be paid their value (quantum meruit), ${ }^{146}$ there is nothing to which a trust might attach. If a service results in the creation of a new asset, then the enrichment is an asset capable of being the subject matter of a trust, in which case it is at least possible that a trust could be raised in response to that unjust enrichment.

If an unjust enrichment consists of the improvement of an existing asset, and not the creation of a new asset, then a trust should not be raised in response to that unjust enrichment. The cases in which improvements have led to the creation of trusts, either of the family home or in other contexts through the use of proprietary estoppel, involve detrimental reliance on expectations. As discussed above, these are constructive trusts raised to perfect those expectations, not to effect restitution of unjust enrichment. Unjust enrichment, by itself, cannot justify the creation of a trust in these circumstances. It is possible that an equitable lien over the improved asset could be raised in response to that unjust enrichment. However, this is a personal claim for restitution of the value of the improvement, secured by the lien. ${ }^{147}$ The defendant can choose to satisfy the claim from other resources without disposing of the asset. ${ }^{148}$ In contrast, a trust gives the plaintiff beneficial ownership of all or a part of that asset. That level of interference with the defendant's ownership of an asset is justified when that asset was acquired at the plaintiff's expense, but not when it has merely been improved. ${ }^{149}$

The second requirement for raising a trust to effect restitution of unjust enrichment is that the asset, which constitutes the unjust enrichment, has not been fully and freely owned by the defendant before the right to restitution arises. If, at any time, the defendant has the unfettered beneficial ownership of that asset and the right to dispose of it as he or she pleases, then any subsequent right to restitution should be limited to a personal claim for payment of the value of that asset. The plaintiff could not complain if the defendant disposed of the asset before the right to restitution arose. The continued existence of that asset in the hands of the defendant is fortuitous and does not justify the creation of a trust. ${ }^{130}$ This follows the important distinction between trust and debt, set out by Channell J. in Henry v. Hammond:

Deglman v. Guaranny Trust Co. of Canada, [1954] S.C.R. 725, [1954] 3 D.L.R. 785; Birks, “In Defence of Free Acceptance," supra note 102 at 132-35; cf. J. Beatson, "Benefit, Reliance and the Structure of Unjust Fnrichment" (1987) 40 Current L.egal Problems 71; revised in J. Beatson, The Use and Abuse of Unjust Enrichment (Oxford: Clarendon Press, 1991) 21-44.

Millett, supra nole 43 inl 414.

Litman, supra note 140 at 456.

See Smith, The law of Tracing, supra note 104 at 351-53, 367-68; R. Chambers, "Tracing, Trusts and Liens" (1997) 11 Trust L. Int. 86.

Sec Eldan Services Led. v. Chandag Motors Lid., [1990] 3 All E.R. 459 at 461. 
It is clear that if the terms upon which the person receives the money are that he is bound to keep it separate, either in a bank or elsewhere, and to hand that money so kept as a separate fund to the person entitled to it, then he is a trustee of that money and must hand it over to the person who is his cestui que trust. If on the other hand he is not bound to keep the money separate, but is entilled to mix it with his own money and deal with it as he pleases, and when called upon to hand over an equivalent sum of money, then, in my opinion, he is not a trustec of the money, but merely a debtor. ${ }^{131}$

This principle can be seen at work in cases where money is paid for a consideration which subsequently fails. The recipient obtains the full beneficial ownership of the money when it is paid. Although the payer is entitled to restitution of that amount of money when the consideration for the payment fails, as Saville L.J. said in Citardian Ocean Cargoes Lid. v. Banco do Brasil SA, "there is neither room nor need for a trust in this case."152 A trust is possible where the consideration fails at the outset ${ }^{153}$ or where there is some fetter on the recipient's ownership of the money between receipt and the failure of consideration. ${ }^{154}$ However, in these cases, the recipient is not entirely free to spend the money before the right to restitution arises. ${ }^{155}$

\section{WHIEN IS A TRUST APPROPRIATE?}

The two requirements discussed above (that the unjust enrichment is an asset capable of being the subject matter of a trust and that the defendant did not obtain the full beneficial ownership of that asset before the right to restitution arose) provide a solid frame in which to build a coherent body of law regarding the use of a trust to effect restitution of unjust enrichment. However, the frame is a large one and more work needs 10 be done. There are many cases falling within that frame which some commentators regard as unsuitable for a trust. Take Chase Manhattan Bank NA v. Israel-British Bank (London) Ltd. as an example. ${ }^{136}$ The plaintiff bank paid U.S. $\$ 2 \mathrm{M}$ to the defendant bank by mistake shortly before the defendant became insolvent. Goulding J. declared that the defendant held that money in trust for the plaintiff from the moment of receipt and that the plaintiff could attempt to trace that money into assets in which it was invested. This case meets the two requirements set out above and

Henry v. IJammond, [1913] 2 K.B. S15 at 521; approved in MA Hanna Co. v. Provincial Bank of Canada, [1935] S.C.R. 144 at 167-68, [1935] I D.L.R. 545 at 565-66; sce Oosterhoff \& Gillese, supra note 43 at 70.

1s4 Ferguson v. Ciry of Toronto, [1944] 3 D.L.R. 317 (Ont. C.A.); Re Namua Goldmines Lid.. [1955] 1 W.L.R. 1080; Re Stefaniuk and Toronto Dominion Bank (1979), 100 D.L.R. (3d) 190 (Man. Q.B.); Re EVTR, [1987] B.C.L.C. 646 (C.A.).

13s Chambers, Resulling Trusts, supra note 43 at 148.53.

18. Supra note 144. 
has considerable support. ${ }^{157}$ Yet, there are distinguished judges and lawyers who regard it as wrongly decided. ${ }^{138}$ This controversy needs to be resolved.

If the defendant is unjustly enriched by the receipt of an asset, and is required to make restitution of that unjust enrichment, on what basis is it decided whether the defendant must give up the asset itself or merely its value in money? The Supreme Court of Canada has provided little guidance on this issue. The cases in which the court has discussed both unjust enrichment and trusts involve either restitution for wrongs, like Soulos v. Korkontzilas, or perfection of expectations, like Pertkus v. Becker. The factors relevant to the creation of a trust in the latter category of cases, such as the expectations of the parties, a "special link" to the asset, and the relative contributions to the relationship, ${ }^{159}$ are of no help when considering an entitlement to restitution of unjust enrichment which consists of an asset acquired at the expense of a plaintiff who was unaware of the transfer or was operating under mistake, duress, undue influence, or incapacity.

This is not intended as a criticism of the Supreme Court. The law of unjust enrichment has developed rapidly in recent years and it will take time to sort through the difficult issues that this has raised. ${ }^{160}$ The highest courts in Australia, Canada, and England have considered several aspects of the modern law of unjust enrichment, but have not had the opportunity to consider carefully the creation of trusts through unjust enrichment. For example, in Westdeutsche Landesbank Girozentrale v. Islington London Borough Council, ${ }^{161}$ the House of Lords decided that money paid to the defendant council under a void contract of loan was not held on trust for the plaintiff bank. However, this was not the central issue in the case, which concerned the plaintiff's entitlement to compound interest. The law lords were not asked to consider the nature of the defendant's unjust enrichment and, therefore, could not explore the issue of when a trust is an appropriate response to that unjust enrichment.

Academic lawyers have suggested several answers to this question. Some involve factors relating to the nature of the unjust enrichment. Others do not. An example from the latter category is the suggestion that the defendant's insolvency can be a determining factor, either as a justification for creating a trust (because a personal claim for the value of the asset would be inadequate $)^{162}$ or as a reason for destroying it (because it gives the plaintiff an unfair preference over the defendant's creditors). ${ }^{163}$

S. Gardner, An Introduction to the Law of Trusts (Oxford: Clarendon Press, 1990) at 233-34: Maddaugh \& McCamus, supra note 13 at 95, 239-40; Goode, "Property and Unjust Enrichunent." supra note 36 at 229; Goff \& Jones, supra note 143 at 130-32: Smith. The Law of Tracing, supres note 104 at 14, 296; Chambers, Resulting Trusis, supra note 43 at 129-31. Sec Westdeutsche Landeshank Girozentrale v. Islington LBC, [1996] A.C. 669, [1996] 2 All I:.R. 961 at 996-97; Millett, supra note 43 at 412-13; Burrows, Restitution, sinpra note 12 at 36-38.

See Peler v. Beblow, stupro nole 108 at 637-41, 649-54.

Ste M. Melnnes, suypra note 19.

Supra note 158.

Peser v. Beblow, supra note 108 at 652; Restatement of Restitution, supra note 21 at 645-47; see Maddaugh \& McCamus, supra note 13 at 94-95.

Goff \& Jones, supra note 143 at $95-98$. 
However, it is difficult to understand why an event, which is wholly unrelated to the unjust enrichment that generates the trust, should affect the creation or continuation of that property right. ${ }^{164}$ Subsequent events can bring about the termination of a trust, such as the expiry of a limitation period, ${ }^{165}$ the acquisition of the trust assets by a bona fide purchaser for value without notice of the trust, ${ }^{166}$ or possibly the trustee's change of position in reliance on his or her apparent entitlement to the trust assets. ${ }^{167}$ Unlike the defendant's insolvency, these are events relating to the unjust enrichment to which the trust responds. Allowing insolvency to dictate the creation or destruction of the trust would, as Mr. Oditah said, "give unsecured creditors a perverse incentive to make 'strategic' use of insolvency proceedings and encourage opportunistic behaviour." ${ }^{168}$

The better approach is to make the trust depend on the nature of the unjust enrichment to which it responds. However, this is not an easy task. In each case within the frame (for which a trust is a possible response to unjust enrichment), the enrichment is an asset which the law says the defendant should not have received or be permitted to retain for his or her own benefit. If only some of these unjust enrichments give rise to a trust, it is necessary to identify some characteristics of the unjust enrichment which give rise to an equitable property right. There are two ways to distinguish one unjust enrichment from another: (a) by the nature of the enrichment and (b) by the reason why that enrichment is unjust.

First, as discussed above, a trust is not possible unless the enrichment is an asset capable of being the subject matter of a trust. Can this category be narrowed further? Probably not. It has been suggested that a trust should arise only where the unjust enrichment is land or a rare chattel and, therefore, a personal claim for its value would not be an adequate substitute for specific recovery. ${ }^{169}$ As discussed above, this is one of the factors used to decide whether a contract of sale is specifically enforceable. Although the proposal has merit, it is not the path the law has chosen. There are many cases in which the plaintiff was entitled to specific restitution of ordinary chattels or a fund of money. ${ }^{170}$ Also, there are other cases, where a trust arose because the defendant purchased an asset using value which could be traced from the plaintiff. ${ }^{171}$ In many of these cases, the asset purchased and held in trust was land, but that cannot

See S. Gardner, "The Element of Discretion" in P. Birks, ed., The Frontiers of Liability, vol. 2 (Oxford: Oxford University Press, 1994) 186 at 200; D.M. Paciocco, "The Remedial Constructive Trust: A Principled Basis for Priorities Over Creditors" (1989) 68 Can. Bar Rev. 315 at 339. Taylor v. Davies, [1920] A.C. 636 (P.C.); JLO Ranch Led. v. Logan (1987), 54 Alta. L.R. (2d) 130.

Hawker v. Hawker (1969), 3 D.L.R. (3d) 735 (Sask.).

Nolan, supra note 103 at 175-85.

F. Oditah, "Assets and the Treatment of Claims in Insolvency" (1992) 108 L.Q.R. 459 at 472.

M. Cope, Constructive Trusts (Sydney: Law Book Co., 1992) at 487; also see Restatement of Restitution, supra note 21 at 664-65.

Clough v. London \& NI Rail Co. (1871), L.R. 7 Exch. 26; Lady Hood of Avalon v. Mackinnon, [1909] I Ch. 476; Newons of Wembley Lid. v. Williams, [1964] 2 All E.R. 135, aff [1964] 3 All E.R. 532 (C.A.); Gibbon v. Mitchell, [1990] I W.L.R. 1304, 2 All E.R. 338.

Simpson-Sears Lid. v. Fraser (1974), 54 D.L.R. (3d) 225, 7 O.R. (2d) 61; Re Kolari (1981), 36 O.R. (2d) 473. 
be the factor which justified the trust. The plaintiff did not lose that land or choose to purchase it and there is no reason why the plaintiff's entitlement to restitution should be affected by the defendant's choice of investment. The trust in this situation arises regardless of the nature of the asset into which the plaintiff's value can be traced.

The second possible way to distinguish one unjust enrichment from another is by the reason why the enrichment is unjust. Three main criteria have been suggested. They each make the creation of the trust depend on whether the plaintiff "voluntarily" caused the unjust enrichment to be transferred to the defendant. The first approach would limit the plaintiff to a personal claim if he or she took the risk of the defendant's insolvency when providing the unjust enrichment. ${ }^{172}$ So, for example, a plaintiff who pays money under a void contract or for a consideration which fails takes that risk, while a plaintiff who pays by mistake might not. The second approach is more restrictive and would limit the trust to cases where the plaintiff had no intention to benefit the defendant whatsoever. Proponents of this theory would say, for example, that a trust would not arise where money is paid by mistake, because the plaintiff intended to benefit the defendant, even though that intention was vitiated by the mistake. ${ }^{173}$ The third approach would restrict the trust to cases where the reason for restitution was any factor (such as mistake, undue influence, or failure of consideration) which showed that the plaintiff did not intend to benefit the defendant in the circumstances. ${ }^{174}$ Although one or more of these avenues of inquiry may lead to a coherent resolution of this issue, there is a great deal of work yet to be done.

In the vast majority of the cases within the frame, "the circumstance calling for restitution is," as Professor Birks states, "a factor negativing voluntariness." 175 Perhaps the plaintiff did not consent to the transfer or made the transfer by mistake, under duress or undue influence, or while lacking capacity. There may have been a failure of consideration (i.e., the defendant was intended to have the asset, but only in particular circumstances which did not come about). In these cases, "the explanation of the response is always reducible in the simplest terms to the statement that the plaintiff did not mean the defendant to have the money in question or the other enrichment, whatever it might be."176 It seems odd to say, on one hand, that defendants must make restitution because they received assets they were not intended to have and, on the other hand, that the defendants can keep those assets and give up their value in money because the transfer was "voluntary." Having decided that a lack of voluntariness makes the receipt of an asset unjust, it is then difficult (though perhaps

Paciocco, supra note 164; E.L. Sherwin, "Constnuctive Trusts in Bankruptcy" [1989] U. Illinois L. Rev. 297; Maddaugh \& McCamus, supra note 13 at 95-96, 327. Millett, supra note 43 at 413 ; sec Burrows, Restitution, supra note 12 at 107.

Birks, "Restitution and Resulting Trusts," supra note 3 at 346-47, 369-72; P. Birks, "Trusts Raised to Reverse Unjust Enrichment: The Westdeutsche case" [1996] R.L. Rev. 3 at 24; Chambers, Resulling Trusts, supra note 43 at 112, 142, 169; also see S. Worthington, "The Proprietary Consequences of Contract Failure" in F. Rose, ed., Failure of Contracts (Oxford: Hart Publishing, 1997) at 67. 
not impossible) to make the particular restitutionary response to that unjust enrichment depend on the level of voluntariness. ${ }^{177}$

Unjust enrichments have given rise to trusts or the specific recovery of assets in cases where the reason for restitution was incapacity, fraud, mistake, duress, undue influence, unconscionable dealing, or failure of consideration. ${ }^{178}$ All of the factors "negativing voluntariness" seem to be capable of generating a property right to restitution. If courts wish to restrict the possibility of a property right to some subset of these cases, an adjustment of existing law will be necessary. Also, courts may need to consider carefully whether trusts can be raised by enrichments which are unjust for rcasons other than non-voluntariness. For example, if the reason for restitution was public policy rather than any impairment or qualification of the plaintiff's intention to benefit the defendant, should the defendant be required to return the asset itself or merely its value in money? That may depend on the particular policy generating the plaintiff's right to restitution. In any event, it is clear that more work needs to be done in this area.

Whether a trust arises in addition to a common-law personal claim for restitution of unjust enrichment is a question which is difficult to answer with confidence. So too is the question whether a trust arises in cases where the plaintiff is entitled to rescind or rectify a transaction and recover legal title to an asset. Does the plaintiff in this situation have an equitable property right to the asset pending recovery of the legal title? There is a long line of authority which says that the plaintiff's equitable property right arises when he or she obtains the right to rescind or rectify the transfer to the defendant, ${ }^{179}$ but this has been challenged recently. ${ }^{180}$

As a general principle, if a defendant in a court of equity can be compelled to transfer an asset to the plaintiff, the court regards the plaintiff as the beneficial owner of that asset from the moment that right arises. As discussed above, this principle is at work when a specifically enforceable contract of sale gives rise to a constructive trust for the purchaser. It was also used in $A-G$ Hong Kong v. Reid to raise a constructive trust in response to a wrong. Lord Templeman said:

See R.M. Goode. "Ownership and Obligation in Commercial Transactions" (1987) 103 1..Q.R. 433 at 439; Birks. "Restitution and Resulting Trusts," supra note 3 at 357; Burrows, Restitution, supra note 12 at 42; Smith. The Law of Tracing, supra note 104 at 296. Scc Chambers, Resulting Trusts, supra notc 43 at c. 5, 6, 7.

Siump v. Gaby (1852), 2 De GM\&G 623, 42 E.R. 1015; Lenty v. Ilillas (1858), 2 De G\&J I10, 44 L.R. 929; Gresky v. Mousley (1859), 4 De G\&J 78, 45 E.R. 31; Dickinson v. Burrell (1866), 1.R. I Eq. 337; Melbourne Banking (Corp. v. Brougham (1882), 7 App. Cas. 307 (P.C.); In re Garnett (1886), 33 Ch. D. 300 (C.A.); Craddock Brothers v. Humt, [1923] 2 Ch. 136 (C.A.); LateC Imvestments l.td. v. Hotel Terrigal Pty l.td. (1965), 113 C.I.R. 265; Blacklocks v. JB Developments (Giodalming) l.d.. [1982] Ch. 183; Civimess plc v. Saumders, [1988] I W.L.R. 863 al 870 (C.A.). aff d [1990] 2 ^.C. 663; also sec Restatement of Restimution, supra note 21 at 649-50.

in! Lonrho plc v. Fayed (No. 2), [1992] I W.1.R. I at |1-12; Bristol and West Building Sociery v Mothew, [1996] 4 All IE.R. 716 at 698 (C.A.): Millet1, supra note 43 at 416; see Smith, The Law' of Tracing, supra note 104 at 365. 
As soon as the bribe was received it should have been paid or transferred instanter to the person who suffered from the breach of duty. Equity considers as done that which ought to have been done. As soon as the bribe was received, whether in cash or in kind, the false fiduciary held the bribe on a constructive trust for the person injured. ${ }^{\text {InI }}$

The creation of a trust for the plaintiff, in cases where he or she has the right to rescind or rectify a transaction and thereby recover an asset, is consistent with this general principle. In all three situations, equity considers as done that which ought to have been done and regards the plaintiff as the equitable beneficial owner of the asset. It does not matter that rescission or rectification are discretionary remedies. So is the specific performance which gives rise to the constructive trust on a contract of sale.

It might be said that the plaintiff is not entitled to recover the asset until he or she elects to rescind or rectify the transaction. However, the right to rescind or rectify arises at the outset even if the plaintiff is not aware of that right. Therefore, it is possible that the trust arises at the outset and comes to an end if the right to rescind or rectify the transaction is lost (through election, delay, or otherwise). ${ }^{182}$ This is similar to the constructive trust which arises on a contract of sale of land. If, at any time, the contract is specifically enforceable, a trust arises regardless of the parties' knowledge of that right. Should the contract cease to be specifically enforceable, then the trust of the land comes to an end.

At the very least, a plaintiff who can elect to rescind or rectify a transaction, and thereby recover property, must be in a similar position to someone who has an option to purchase property. If the exercise of an option to purchase will lead to a specifically enforceable contract, that option is an equitable property right in the asset that may be purchased. This is because, as Martland J. said in Canadian Long Island Petroleums Lld. v. Irving Industries Lid., "forthwith upon the granting of the option, the optionee upon the occurrence of certain events solely within his control can compel a conveyance of the property to him." 183 This must also be true of any election to rescind or rectify which will give rise to a right to recover an asset in a court of equity. If the trust does not arise until the election is made, then the plaintiff must have a lesser equitable property right in the recoverable asset from the moment the right to make the election arises.

As this part of the essay illustrates, the creation of trusts to effect restitution of unjust enrichment involves difficult issues which deserve further academic and judicial attention. However, it is doubtful whether an essay on constructive trusts is the proper forum for this inquiry. There are good reasons to suspect that the trust being discussed in this section is not constructive, but resulting. 


\section{B. IS tile Trust CONSTRuctive or Resulting?}

In North America, it is often assumed that the trust which responds to unjust enrichment is constructive. In the U.S.A., the link between constructive trusts and unjust enrichment was firmly established in the 1930s, when the American Law Institute decided to place the law of constructive trusts in the Restatement of the Law of Restitution and not in the Restatement of the Law of Trusts. In Canada, that link was made in the 1980s, with Pettkus v. Becker. However, it was never clear why the resulting trust is not generally regarded as a response to unjust enrichment.

The American Law Institute distinguishes between resulting and constructive trusts as follows:

A resulting trust arises where a transfer of property is made under circumstances which raise an inference that the person making the transfer or causing it to be made did not intend the transferee to have the beneficial interest in the property transferred. A constructive trust is imposed not because of the intention of the parties but because the person holding the title to property would profit by a wrong or would be unjustly enriched if he were permitted to keep the property. ${ }^{1 \text { H }}$

Although this clearly separates from the others those constructive trusts which effect restitution of assets acquired in breach of duty, it does not provide a meaningful distinction between resulting trusts and those constructive trusts which respond to unjust enrichment. As discussed above, where the receipt of a benefit is regarded as an unjust enrichment, it is most often because of some factor (such as ignorance, mistake, duress, undue influence, or failure of consideration) which shows that the plaintiff did not intend to benefit the defendant in the circumstances. The trust which arises in such cases could be either resulting or constructive, according to the American Law Institute's definition. ${ }^{\text {ss }}$

Despite the dominant North American assumption that "unjust enrichment lies at the heart of the constructive trust,"186 as discussed above, the earliest use of the constructive trust appears to be to perfect a specifically enforceable contract of sale. ${ }^{187}$ This was followed in 1726 by Keech v. Sandford, where the constructive trust was used to effect restitution of an asset acquired in breach of fiduciary duty. ${ }^{188}$ Thirteen years later, in Ryall v. Ryall, ${ }^{189}$ one finds an early example of a trust used to effect restitution of unjust enrichment. A testator gave several legacies to the plaintiffs. Instead of paying the legacies, the executor used that money to purchase land in his own name. On his death, the land passed to his infant heir at law (the defendant). The plaintiffs wanted that land to be used to pay their legacies. Lord Hardwicke C. said "Courts of equity have been very cautious how they follow money which has been laid

Restatement of Restitution, supra note 21 at 642.

Ste Scane, supra note 113 at 265.

Pellkus v. Becker, supra notc 20 at 273, Dickson J.

Sec supra notes $51,52$.

See supra note 15.

(1739), I Atk. 59, 26 E.R. 39 [hercinafter Ryall cited to E.R.]. 
out in land, because it has no ear mark."190 However, if the plaintiffs could prove that money from their testator's estate had been used to purchase the land, the defendant would hold it in trust for them.

This trust arose because money, which should have been paid to the plaintiffs, was used by the executor, without their knowledge or consent, and could be traced into the land in the hands of the defendant. There was, as Dickson J. said in Pettkus v. Becker, "an enrichment, a corresponding deprivation and absence of any juristic reason for the enrichment." 191 However, the trust raised in response to that unjust enrichment was not constructive, but resulting. As Lord Hardwicke C. said, "the means of coming at this by way of resulting trust is excepted out of the statute of frauds; if the estate is purchased in the name of one, and the money paid by another, it is a trust notwithstanding there is no declaration in writing by the nominal purchaser." 192

There is a long tradition of using the resulting trust as a response to unjust enrichment in Canada. Most lawyers and judges are familiar with cases where a resulting trust was used, on the failure of an express trust, to effect restitution of the trust assets to the settlor of that trust. The resulting trust arises in those cases because the trustees were not intended to keep those assets for their own benefit. ${ }^{193}$ Also familiar are cases where no express trust was involved, but a resulting trust arose because the plaintiff purchased assets for, or transferred assets to, a defendant who was not intended to have those assets for his or her own benefit. ${ }^{194}$

The resulting trust has also been used in Canada to effect restitution in less familiar situations. In Merchants Express Co. v. Morton, ${ }^{195}$ the plaintiffs were entitled to a resulting trust of a hotel in Toronto, purchased with money that could be traced from assets stolen from the plaintiffs during a train robbery in the U.S.A. In Goodfellow v. Robertson, ${ }^{196}$ Spragge C. relied on Ryall v. Ryall to hold that land purchased with money belonging to a person lacking mental capacity would be held on resulting trust for that person. In Sharp v. McNeil, ${ }^{197}$ a partner misappropriated partnership assets to purchase land in the name of his sister. Townshend C.J. said:

The law is not so liclpless as to leave the party wronged withoul a remedy, and therefore holds the person to whom such a conveyance has been made as a trustee for the righteful owner. In other words a resulting trust follows. ${ }^{10 *}$

191 Supra notc 20 at 273-74.

1'2 Supra note 189 at 39-40.

in Fraser v. Fraser, [1937] 1 W.W.R. 91 (Alia.).

is Niles v. Lake, [1947] S.C.R. 291. [1947] 2 D.L.R. 248.

195 (1868), 15 (ir. 274.

1*. (1871), 18 Gr. 572.

in (1913), 15 D.L.R. 73 (N.S.S.C.A.D.), afTd, (1915) 70 D.L.R. 740 (S.C.C.).

IVX

lbid. at 75. 
In 1981, in Re Kolari, ${ }^{199}$ a bank teller purchased assets with money stolen from her employer. Stortini D.C.J. said, "a resulting trust arises where property is obtained by fraud or theft." 200 This did not receive much attention since the Supreme Court of Canada had just decided Pettkus v. Becker and all eyes were focused on the constructive trust.

There are numerous other cases in which courts have declared a trust to effect restitution of unjust enrichment, but did not say whether the trust was constructive or resulting. North American readers tend to assume they are constructive. Chase Manhattan Bank NA v. Israel-British Bank (London) Lid. provides a good example. As discussed above, ${ }^{201}$ the plaintiff paid money to the defendant by mistake and Goulding $\mathrm{J}$. held that the defendant was a trustee of that money for the plaintiff from the moment of receipt. This is often regarded as a constructive trust. The case involved a question of the proper law to be applied and, on hearing evidence, Goulding J. concluded that a mistaken payment would give rise to a constructive trust under New York law. However, he did not say that a constructive trust would also arise in English law. Instead, he held that the plaintiff had "a continuing right of property recognized in equity," ${ }^{202}$ relying on Sinclair v. Brougham, where Viscount Haldane had classified that property right as a resulting trust. ${ }^{203}$

Does it matter whether the trust responding to unjust enrichment is classified as constructive or resulting? The current level of confusion regarding this response suggests that it does. The constructive trust was developed in equity to perform two main functions: to perfect intentions regarding the beneficial ownership of assets and to effect restitution of assets acquired in breach of duty. The principles which guide the creation of a trust in those situations are inapplicable to cases of unjust enrichment. The modern North American use of the constructive trust as a response to unjust enrichment has suffered from this mismatch.

In contrast, the resulting trust arises when a defendant acquires an asset at the expense of the plaintiff in circumstances which show that the plaintiff did not intend the defendant to enjoy the benefit of the asset. Although this does not cover all cases of unjust enrichment, it may cover all the cases in which a trust should be used to effect restitution of unjust enrichment. This use of the resulting trust could well provide the level of certainty which one finds and expects in other areas of trusts and property law, but which has eluded Canadian courts trying to respond to unjust enrichment with the constructive trust. As Lord Millett said, "the development of a coherent doctrine of proprietary restitution for subtractive unjust enrichment is impossible unless it is based on the resulting trust as traditionally understood."204 


\section{Conclusion}

Pettkus v. Becker created an assumption that constructive trusts in Canada are based on unjust enrichment. Soulos v. Korkontzilas re-affirmed that constructive trusts in Canada still respond to all "the situations in which English courts of equity traditionally found a constructive trust." ${ }^{205}$ In Soulos, McLachlin J. suggested that there are two main categories of events which give rise to constructive trusts: (a) the acquisition of assets in breach of duty and (b) unjust enrichment. ${ }^{206}$ As discussed above, it appears that there are two main categories and that constructive trusts do respond in the former category to effect restitution of assets acquired through wrongdoing. However, the second main category of constructive trusts are raised, not to effect restitution of unjust enrichment, but to perfect intentions to benefit others, usually because those intentions have been detrimentally relied upon or because valuable consideration has been given in exchange.

Trusts do arise in response to unjust enrichment, but only for the purpose of effecting restitution of the unjust enrichment itself. The law has had difficulty working out precisely why and when an unjust enrichment will generate a trust. As suggested above, a trust should arise only where (a) the unjust enrichment is an asset capable of being the subject matter of a trust, (b) the defendant did not acquire the full beneficial ownership of that asset before the plaintiff's right to restitution arose, and (c) the enrichment is unjust because the plaintiff did not intend the defendant to have the benefit of the asset in the circumstances. It turns out that this is a description of the event which gives rise to a resulting trust. There are good reasons to believe that real progress in this area will depend on the proper development of the resulting trust and that constructive trusts will have little or no role in this.

Why has our understanding of the constructive trust progressed so slowly, especially in comparison with many other areas of law which developed rapidly during the twentieth century? A great impediment has been occasioned by the belief that intention has nothing whatsoever to do with the constructive trust. It is true that constructive trusts (and resulting trusts) are not created by the properly manifested intention to create a trust (as are express trusts). However, as Professor Litman said, "It is one thing to say that a constructive trust does not arise from the intention of the parties, but it is a non sequitur to then conclude that the parties' intentions are irrelevant to the question of whether the trust has arisen." 207 In one main category of constructive trusts, an intention to benefit another is, in combination with other factors, the event which calls for the creation of a trust by operation of law.

The belief that intention is irrelevant to the creation of all constructive trusts cannot be reconciled with observations of that trust in many situations. One can see three different reactions to this mismatch. The first (which is encountered in England, Australia, and New Zealand) is despair or resignation. Dr. Elias calls it "the sceptical 
thesis," by which he means "that there is no coherent general scheme for resolving the problems of classification and justification which the rules on constructive trusts raise."208 In other words, constructive trusts cannot be understood as other than a miscellany of trust creating events and it is impossible to progress beyond vague appeals to justice and conscience when attempting to explain the source of such trusts.

The second reaction is to invent additional theories to reconcile observations with the prevailing belief. The North American approach to constructive trusts exemplifies this type of reaction. If all constructive trusts arise independently of the parties' intentions, then perfectionary constructive trusts must be responding to some other event. Dr. Elias calls this "the radical thesis," which attempts to explain all constructive trusts as "means furthering the restitution aim." 209 This explanation requires the distortion of the rules regulating the creation of constructive trusts in many situations (e.g., contracts of sale, secret trusts, mutual wills, incomplete gifts, and family property), the law of unjust enrichment, or both.

The third reaction is to challenge the prevailing belief. This is what Dr. Elias did with what he calls "the third thesis." 110 If one is allowed to say that constructive trusts can respond to intention, then the chaos can be ordered. Constructive trusts arise to effect restitution of assets acquired through breach of duty or to perfect informal intentions to benefit others, while express trusts arise in direct response to properly manifested intentions to create a trust and resulting trusts arise to effect restitution of unjust enrichment. ${ }^{211}$ The categories are not closed since there are other events (e.g., statutes) which create trusts. In other words, there will always be a miscellany of trust creating events, but one which would be greatly reduced by a proper understanding of constructive and resulting trusts.

We must take care not to label as miscellaneous those trusts which can otherwise be explained and take even greater care, if possible, to ensure that the explanation given is accurate. The rational development of the law depends on the clear and correct identification of the events which generate legal rights. This is all the more important when the rights concerned are property rights (and may bind third persons) or arise by operation of law (and may be unintended and unexpected). As long as perfectionary constructive trusts are ignored or misunderstood, this goal will remain beyond our reach. 